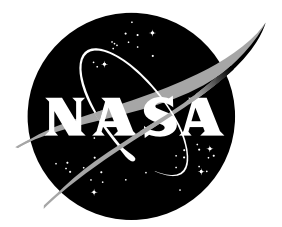

\title{
Magnetic and Electrical Characteristics of Cobalt-Based Amorphous Materials and Comparison to a Permalloy Type Polycrystalline Material
}

William R. Wieserman

University of Pittsburgh, Johnstown, Johnstown, Pennsylvania

Gene E. Schwarze

Glenn Research Center, Cleveland, Ohio

Janis M. Niedra

QSS Group, Inc., Cleveland, Ohio 
Since its founding, NASA has been dedicated to the advancement of aeronautics and space science. The NASA Scientific and Technical Information (STI) Program Office plays a key part in helping NASA maintain this important role.

The NASA STI Program Office is operated by Langley Research Center, the Lead Center for NASA's scientific and technical information. The NASA STI Program Office provides access to the NASA STI Database, the largest collection of aeronautical and space science STI in the world. The Program Office is also NASA's institutional mechanism for disseminating the results of its research and development activities. These results are published by NASA in the NASA STI Report Series, which includes the following report types:

- $\quad$ TECHNICAL PUBLICATION. Reports of completed research or a major significant phase of research that present the results of NASA programs and include extensive data or theoretical analysis. Includes compilations of significant scientific and technical data and information deemed to be of continuing reference value. NASA's counterpart of peerreviewed formal professional papers but has less stringent limitations on manuscript length and extent of graphic presentations.

- TECHNICAL MEMORANDUM. Scientific and technical findings that are preliminary or of specialized interest, e.g., quick release reports, working papers, and bibliographies that contain minimal annotation. Does not contain extensive analysis.

- CONTRACTOR REPORT. Scientific and technical findings by NASA-sponsored contractors and grantees.
- CONFERENCE PUBLICATION. Collected papers from scientific and technical conferences, symposia, seminars, or other meetings sponsored or cosponsored by NASA.

- SPECIAL PUBLICATION. Scientific, technical, or historical information from NASA programs, projects, and missions, often concerned with subjects having substantial public interest.

- TECHNICAL TRANSLATION. Englishlanguage translations of foreign scientific and technical material pertinent to NASA's mission.

Specialized services that complement the STI Program Office's diverse offerings include creating custom thesauri, building customized databases, organizing and publishing research results ... even providing videos.

For more information about the NASA STI Program Office, see the following:

- Access the NASA STI Program Home Page at http://www.sti.nasa.gov

- E-mail your question via the Internet to help@sti.nasa.gov

- Fax your question to the NASA Access Help Desk at 301-621-0134

- Telephone the NASA Access Help Desk at 301-621-0390

- Write to:

NASA Access Help Desk

NASA Center for AeroSpace Information 7121 Standard Drive

Hanover, MD 21076 
NASA/TM-2005-213997

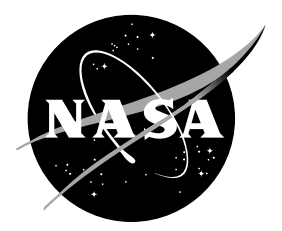

\section{Magnetic and Electrical Characteristics of Cobalt-Based Amorphous Materials and Comparison to a Permalloy Type Polycrystalline Material}

William R. Wieserman

University of Pittsburgh, Johnstown, Johnstown, Pennsylvania

Gene E. Schwarze

Glenn Research Center, Cleveland, Ohio

Janis M. Niedra

QSS Group, Inc., Cleveland, Ohio

Prepared for the

Third International Energy Conversion Engineering Conference sponsored by the American Institute of Aeronautics and Astronautics San Francisco, California, August 15-18, 2005

National Aeronautics and

Space Administration

Glenn Research Center 


\section{Acknowledgments}

The authors would like to acknowledge the NASA Energetics Project of the Enabling Concepts and Technologies

Program for funding this research.

Trade names or manufacturers' names are used in this report for identification only. This usage does not constitute an official endorsement, either expressed or implied, by the National Aeronautics and Space Administration.

Available from

NASA Center for Aerospace Information 7121 Standard Drive

Hanover, MD 21076
National Technical Information Service 5285 Port Royal Road Springfield, VA 22100 


\title{
Magnetic and Electrical Characteristics of Cobalt-Based Amorphous Materials and Comparison to a Permalloy Type Polycrystalline Material
}

\author{
William R. Wieserman \\ University of Pittsburgh, Johnstown \\ Johnstown, Pennsylvania 15904 \\ Gene E. Schwarze \\ National Aeronautics and Space Administration \\ Glenn Research Center \\ Cleveland, Ohio 44135 \\ Janis M. Niedra \\ QSS Group, Inc. \\ Cleveland, Ohio 44135
}

Magnetic component designers are always looking for improved soft magnetic core materials to increase the efficiency, temperature rating and power density of transformers, motors, generators and alternators, and energy density of inductors. In this paper, we report on the experimental investigation of commercially available cobaltbased amorphous alloys which, in their processing, were subjected to two different types of magnetic field anneals: A longitudinal magnetic field anneal or a transverse magnetic field anneal. The longitudinal field annealed material investigated was Metglas ${ }^{\circledR}$ 2714A. The electrical and magnetic characteristics of this material were investigated over the frequency range of 1 to $200 \mathrm{kHz}$ and temperature range of 23 to $150{ }^{\circ} \mathrm{C}$ for both sine and square wave voltage excitation. The specific core loss was lower for the square than the sine wave voltage excitation for the same maximum flux density, frequency and temperature. The transverse magnetic field annealed core materials include Metglas ${ }^{\circledR} 2714 \mathrm{AF}$ and Vacuumschmelze $6025 \mathrm{~F}$. These two materials were experimentally characterized over the frequency range of 10 to $200 \mathrm{kHz}$ for sine wave voltage excitation and $23{ }^{\circ} \mathrm{C}$ only. A comparison of the $2174 \mathrm{~A}$ to $2714 \mathrm{AF}$ found that $2714 \mathrm{AF}$ always had lower specific core loss than $2714 \mathrm{~A}$ for any given magnetic flux density and frequency and the ratio of specific core loss of 2714A to $2714 \mathrm{AF}$ was dependent on both magnetic flux density and frequency. A comparison was also made of the 2714A, 2714AF, and $6025 \mathrm{~F}$ materials to two different tape thicknesses of the polycrystalline Supermalloy material and the results show that $2714 \mathrm{AF}$ and $6025 \mathrm{~F}$ have the lowest specific core loss at $100 \mathrm{kHz}$ over the magnetic flux density range of 0.1 to 0.4 Tesla.

\section{Nomenclature}

$I^{2} R \quad$ winding power losses measured in Watts

$B-H \quad$ hysteresis plot of magnetic flux density $B$ versus magnetic field intensity $H$

$S C L \quad$ specific core loss measured in Watts per pound, Watts per cubic meter, or Watts per cubic centimeter

$B_{M} \quad$ maximum magnetic flux density measured in Tesla

$f \quad$ electrical frequency measured in Hertz

$i_{p}(t) \quad$ the primary excitation current measured in Amperes

$e_{s}(t) \quad$ the secondary induced voltage measured in volts

$T \quad$ the core temperature measured in Celsius

\section{Introduction}

Almost all power electronic circuits, such as inverters and converters, require power magnetic components. These magnetic components function as either power transfer or energy storage devices, and in some cases fulfill both needs. Increasing the operating frequency of the power magnetic components will reduce their mass and size ${ }^{1}$. Increasing their operating temperature will admit smaller cooling radiators or heat sinks and also reduce the complexity of the heat transport system. 
Magnetic components designers are always looking for improved soft ferromagnetic core materials to increase the efficiency, temperature rating and power density of transformers, motors, generators and alternators, and energy density of inductors. The primary means to increase the transformer's efficiency is to decrease the loss in the magnetic core material and the $I^{2} R$ or Joulean loss in the windings. The primary means to increase the transformer's power density is to increase the frequency. But increasing the frequency without a decrease in the magnetic flux density will increase the core loss. So in most instances, the trade-off between power density, efficiency, and temperature rise comes down to a trade between operating frequency and magnetic flux density of the magnetic core material and current density in the windings. It should be noted that increasing the frequency will also increase the $A C I^{2} R$ loss in the windings.

A very essential element in the design of power magnetic components is the knowledge of the electrical and magnetic properties and characteristics of available soft magnetic core materials. Properties such as saturation induction, Curie temperature, and thermal conductivity can generally be obtained from the product literature provided by the manufactures and fabricators of soft magnetic materials. However, experimental characterization data such as the effect of temperature, frequency, flux density, lamination or tape thickness, and excitation waveform on the core loss and dynamic $B-H$ hysteresis loop are not always readily available. In many instances neither the manufacturer's product literature nor the technical literature provide the required information. This almost total lack of information is particularly true for non-sinusoidal excitation core loss data. In most power electronic circuits such as switched mode power supplies, the excitation voltage impressed on the converter's transformer is non-sinusoidal, and in $D C$ - $D C$ converters such as the push-pull and bridge converters, voltage excitation waveform is a square wave. Because of this lack of non-sinusoidal excitation core loss data, the transformer designer for switched mode power supplies, must generally fall back to using core loss data obtained for sine wave voltage excitation, assuming that even this data exists. Because of this lack of design data, the NASA Glenn Research Center initiated an experimental program to investigate the electrical and magnetic characteristics of candidate soft magnetic materials for temperatures up to $300{ }^{\circ} \mathrm{C}$ and frequencies up to $1 \mathrm{MHz}$ for both sine and square wave voltage excitations.

The core loss, that is, the power loss, of soft magnetic materials is a function of the excitation frequency, magnetic flux density, temperature, type of excitation (voltage or current), excitation waveform (sine, square, etc.), and lamination or tape thickness. A summary of core loss theory is given in Reference 8. In previously published papers ${ }^{2,3,4,5,6,7,8}$ we have reported on the specific core loss, $S C L$, and dynamic $B-H$ hysteresis loop behavior for several polycrystalline, nanocrystalline, and amorphous soft magnetic materials. In this previous research we investigated the effects of magnetic flux density, frequency, temperature, tape thickness, and excitation waveform for voltage excitation on the $S C L$ and dynamic $B-H$ hysteresis loops. The soft magnetic materials investigated included an $80 \mathrm{Ni}-\mathrm{Fe}$ polycrystalline alloy ${ }^{2,3,6,8}$, two $50 \mathrm{Ni}-\mathrm{Fe}$ polycrystalline alloys ${ }^{4}$, a $2 \mathrm{~V}-49 \mathrm{Fe}-49 \mathrm{Co}$ polycrystalline alloy $^{5}$, a grain oriented $3 \mathrm{Si}-\mathrm{Fe}$ polycrystalline alloy ${ }^{5}$, two iron-based amorphous alloys ${ }^{3,4}$, two cobalt-based amorphous alloys ${ }^{7}$, and an iron-based nanocrystalline alloy ${ }^{7}$.

The difference in core loss and $B-H$ loop behavior resulting from either a sine or square wave voltage excitation was previously investigated by C.H. Chen ${ }^{9}$, T. Sato and Y. Sakaki ${ }^{10}$, and G.E. Schwarze, W.R. Wieserman, and J.M. Niedra ${ }^{6}$. Chen investigated several materials and depending on material and flux density, the test frequencies ranged between 10 and $100 \mathrm{kHz}$. Chen found for like conditions of maximum magnetic flux density, $B_{M}$, and frequency, $f$, that the core loss was larger for sine wave than for square wave voltage excitation. Sato and Sakaki tested materials similar to those investigated by Chen, but extended the test frequency up to $1 \mathrm{MHz}$. Their results were similar to those reported by Chen. In these papers there is no indication that their tests were conducted for temperatures beyond $50{ }^{\circ} \mathrm{C}$. Schwarze, Wieserman, and Niedra did extensive experimental tests on an $80 \mathrm{Ni}-\mathrm{Fe}$ alloy known in the trade as Supermalloy. Their investigation covered the frequency range of $1 \mathrm{kHz}$ to $50 \mathrm{kHz}$ and temperature range of 23 to $300{ }^{\circ} \mathrm{C}$. An analytical investigation of the sine and square wave $S C L$ always found that the sine wave $S C L$ for the same $B_{M}, f$, and $T$ was always greater than the square wave $S C L$. It was also found that the ratio of sine-to-square $S C L$ varied up to 22 percent $^{6}$ depending on $B_{M}, f$, and $T$.

In this paper, we will report on an experimental investigation of commercially available cobalt-based amorphous alloys which, in their processing, were subjected to two different types of magnetic anneals: a longitudinal or transverse magnetic field anneal. The longitudinal magnetic field anneal is applied parallel to the rolling direction and in the plane of the magnetic tape while the transverse magnetic field anneal is applied perpendicular to the rolling direction and in the plane of the tape.

We previously investigated very thin tape Permalloy $(80 \mathrm{Ni}-20 \mathrm{Fe}-4 \mathrm{Mo})$ type polycrystalline material and found the 1/4-mil thick tape to have very low core loss. The Permalloy type materials are relatively "old" technology materials compared to the relatively "new" amorphous magnetic materials. The $S C L$ for this $1 / 4$-mil thick tape will be included in a comparison to several amorphous materials. 
In addition, dynamic $B-H$ loops for the materials investigated in this paper will be presented to show the effects of frequency and excitation waveform on the size and shape of these loops.

\section{Materials and Test Core Description}

The amorphous longitudinal magnetic field annealed Metglas ${ }^{\circledR} 2714 \mathrm{~A}$ test cores were wound by Magnetics, a Division of Spang and Company, in the form of a toroid with nominal tape thickness of $20 \mu \mathrm{m}$. The width of the tape was 0.25 inch and nominal core dimensions were $\mathrm{OD}=1.25$ inches and ID $=1.0$ inch. The amorphous transverse magnetic field annealed Metglas ${ }^{\circledR} 2714 \mathrm{AF}$, also known as MAGNAPERM ${ }^{\circledR}$, test core was provided to NASA Glenn Research Center as a sample toroid core by Allied Signal, Inc., Parsippany, NY. The tape thickness of the toroid was also a nominal $20 \mu \mathrm{m}$ with core dimensions of $\mathrm{OD}=1.75$ inches, $\mathrm{ID}=0.875$ inches and height $=$ 0.375 inches.

The manufacturer's literature ${ }^{11}$ for the $2714 \mathrm{~A}$ and $2714 \mathrm{AF}$ gives a saturation flux density of $0.57 \mathrm{~T}$, saturation magnetostriction of less than $1 \mathrm{ppm}$, Curie temperature of $225 \mathrm{C}$, crystallization temperature of $550{ }^{\circ} \mathrm{C}$, continuous operating temperature of $90{ }^{\circ} \mathrm{C}$, and mass density of $7.59 \mathrm{gm} / \mathrm{cm}^{3}$. The composition of $2714 \mathrm{~A}$ and $2714 \mathrm{AF}$ according to the manufacturer's Material Safety Data Sheet ${ }^{12}$ in weight percent is Cobalt $(75-90)$, Iron (7 - 13), Nickel (1 - 5), Silicon (7 - 13), and Boron (1 - 5).

\section{Experimental Description}

The measurement system used to measure, compute, plot, and display the electrical and magnetic characteristics of the test core material is shown in Figure 1. A key element of the measurement system is the power amplifier used to excite the core material. The introduction of amplitude or phase distortion by the amplifier, and this is particularly true for square wave voltage excitation, will produce erroneous core loss and $B-H$ dynamic loops. The method used to obtain the $S C L$ and $B-H$ dynamic loops from the primary excitation current, $i_{p}(t)$, and the secondary induced voltage, $e_{s}(t)$, waveforms is described and discussed in Reference 2 .

The electrical and magnetic characteristics of the 2714A material were tested over the frequency range of 1 to $200 \mathrm{kHz}$ and temperature range of 23 to $150^{\circ} \mathrm{C}$ for both sine and square wave voltage excitation. The electrical and magnetic characteristics of the $2714 \mathrm{AF}$ material were tested over the frequency range of 10 to $100 \mathrm{kHz}$ for sine wave voltage excitation and $23{ }^{\circ} \mathrm{C}$ only. $B_{M}$ was either the saturation flux density for the low frequencies or that $B_{M}$ for which the $S C L$ remained less than $100 \mathrm{~W} / \mathrm{lb}$. Particular attention was given to capturing the required waveforms in the minimum length of time.

\section{Experimental Results and Discussion}

Effects of the $B_{M}, f$, and $T$ on the $S C L$ can best be seen and analyzed for trends by plotting the data as follows:

1. $S C L$ versus $B_{M}$ with $f$ as the parameter for a given $T$.

2. $S C L$ versus $f$ with $B_{M}$ as parameter for a given $T$.

3. $S C L$ versus $T$ with $f$ as parameter for a given $B_{M}$.

The effects of a longitudinal magnetic field anneal (2714A) and transverse magnetic field anneal (2714AF) on the $S C L$ can best be seen and analyzed for trends by plotting the data as follows:

1. Ratio of $2714 \mathrm{~A}$ to $2714 \mathrm{AF} S C L$ versus $B_{M}$ with $f$ as the parameter.

2. Ratio of $2714 \mathrm{~A}$ to $2714 \mathrm{AF} S C L$ versus $f$ with $B_{M}$ as the parameter.

\section{A. Longitudinal Magnetic Field Anneal (2714A)}

The effects of $B_{M}$ and $f$ on the $S C L$ at a temperature of $23{ }^{\circ} \mathrm{C}$ for sine and square wave voltage excitation are shown in the Figure 2 and 3 plots, respectively for the 2714A material.

The curve for a given $f$ shows that the $S C L$ tends to increase nearly linearly with increasing $B_{M}$ on a $\log$-log scale for both the sine wave excitation (Figure 2a) and the square wave excitation (Figure 2b). Likewise, the plots for a given $B_{M}$ shows that the $S C L$ tends to increase nearly linearly on a $\log -\log$ scale with $f$ for both sine wave excitation (Figure 3a) and square wave excitation (Figure 3b). A comparison of either Figure 2a (sine wave excitation) to Figure $2 \mathrm{~b}$ (square wave excitation) or Figure $3 \mathrm{a}$ (sine wave excitation) to Figure $3 \mathrm{~b}$ (square wave excitation) shows that the $S C L$ is larger for sine wave excitation than for square wave excitation. For example, at $B_{M}=0.4$ Tesla, the ratio of sine-to-square wave $S C L$ varies from 1.03 at $1 \mathrm{kHz}$ to 1.09 at $50 \mathrm{kHz}$. In general, this is the range of variation of the sine-to-square $S C L$ ratio for the other $B_{M}$ values tested. This same comparison of sine-to-square wave $S C L$ ratio was previously done for a 1-mil thick tape Supermalloy toroid at $B_{M}=0.4$ Tesla at $23{ }^{\circ} \mathrm{C}^{6}$. In this case, the ratio varied between 1.17 and 1.22 over the frequency range of 1 to $50 \mathrm{kHz}$. This comparison readily shows that the sine-to-square wave $S C L$ ratio is greater for the polycrystalline Supermalloy material than for the amorphous 
2714A material. The reason for this rather large difference in the ratios is not readily apparent and additional experimentation and analysis will be required to determine the underlying cause. However, these results would imply that the core loss mechanism for a polycrystalline magnetic material is different than that for an amorphous magnetic material when subjected to different types of excitation.

Figure 4a (sine wave excitation) and Figure 4b (square wave excitation) plot the $S C L$ as a function of temperature for $B_{M}=0.4$ Tesla with $f$ as the parameter for the 2714A material. The "flatness" of the $S C L$ versus $T$ curves plotted in these figures is seen to be a function of frequency. For 5 and $10 \mathrm{kHz}$, the $S C L$ curves tend to a slight minimum at $100{ }^{\circ} \mathrm{C}$ and then increase in slope from 100 to $150{ }^{\circ} \mathrm{C}$, but the $S C L$ value at $150{ }^{\circ} \mathrm{C}$ is less than that at $23{ }^{\circ} \mathrm{C}$. For 20 and $50 \mathrm{kHz}$, the slope of the $S C L$ curves decreases slightly from 23 to $100{ }^{\circ} \mathrm{C}$ and then the slope increases from 100 to $150{ }^{\circ} \mathrm{C}$, but the $S C L$ value at $150{ }^{\circ} \mathrm{C}$ is greater than that at $23^{\circ} \mathrm{C}$. The relative increase in $S C L$ at $150{ }^{\circ} \mathrm{C}$ is greater for $50 \mathrm{kHz}$ than for $20 \mathrm{kHz}$ compared to the $S C L$ at $23^{\circ} \mathrm{C}$. For $100 \mathrm{kHz}$, the slope of the $S C L$ curve shows a steady increase over the temperature range of 23 to $150^{\circ} \mathrm{C}$.

Figure $5 \mathrm{a}$ (sine wave excitation) and Figure $5 \mathrm{~b}$ (square wave excitation) give a family of dynamic $B-H$ loops for frequencies of $1,5,10,20$, and $100 \mathrm{kHz}$ for $B_{M}=0.4$ Tesla and $T=23{ }^{\circ} \mathrm{C}$ for the $2714 \mathrm{~A}$ material. A comparison of the $B-H$ loops in Figure 5a with those in Figure 5b shows that the shape of the loop is excitation dependent. Sine wave voltage excitation gives rounded corners at $\pm B_{M}$ while square wave voltage excitation gives pointed corners at $\pm B_{M}$. Both sets of loops give a good visual image of how the size or area of the loop increases with frequency due to eddy current loss. Another observation is that the ac coercive force is less for the square wave than for the sine wave excitation for a given frequency. And finally, it should be noted that loops for both sine and square wave excitation are quite symmetrical about the origin. 2714A is a "square-loop" type of material for which the ratio of remanence to maximum flux density approaches unity. "Square loop" types of materials tend to "ratchet" towards either $\pm B_{M}$ and thus give non-symmetrical loops.

Figure 6 gives a good visual picture of a comparison of a 2714A $B-H$ loop for sine and square wave voltage excitation at $B_{M}=0.4$ Tesla, $f=100 \mathrm{kHz}$, and $T=23^{\circ} \mathrm{C}$. It is readily seen that the square wave excitation $B-H$ loop fits entirely within the area of the sine wave excitation $B$ - $H$ loop except for tip areas about $\pm B_{M}$. If these two tip areas are subtracted from the area of the sine wave excitation $B-H$ loop, it is seen that the area (i.e., core loss)

enclosed by the sine wave excitation $B-H$ loop is larger than the area enclosed by the square wave excitation $B-H$ loop.

\section{B. Transverse Magnetic Field Anneal (2714AF)}

The effects of $B_{M}$ and $f$ on the $S C L$ at $23^{\circ} \mathrm{C}$ for sine wave voltage excitation for the transverse annealed 2714AF material are given in Figures 7 and 8. Just as was observed for the longitudinal annealed 2714A, the curve for any given $f$ in Figure 7 shows that the $S C L$ increases nearly linearly with increasing $B_{M}$ on a log-log scale. Likewise, for any given $B_{M}$, Figure 8 shows that the $S C L$ increases nearly linearly with $f$ on a $\log$-log scale.

Our primary interest in $2714 \mathrm{AF}$ is to compare the $S C L$ of the transverse annealed material with the longitudinal annealed 2714A material to determine what advantage 2714A has over 2714AF. Figure 9 gives a comparison of these two material's $S C L$ as a function of $B_{M}$ with $f$ as the parameter at $23^{\circ} \mathrm{C}$; Figure 10 gives this comparison of $S C L$ as a function of $f$ with $B_{M}$ as the parameter at $23{ }^{\circ} \mathrm{C}$. Inspection of the $S C L$ versus $B_{M}$ curves in Figure 10 shows that for any given $B_{M}$, the $S C L$ is lower for the $2714 \mathrm{AF}$ than for the $2714 \mathrm{~A}$ material for any given frequency. Likewise, inspection of the $S C L$ versus $f$ curves in Figure 11 shows that for any given $\mathrm{f}$, the $S C L$ is lower for the $2714 \mathrm{AF}$ than for the 2714A material for any given $B_{M}$.

The results in Figures 9 and 10 clearly show the $S C L$ advantages of the transverse anneal compared to the longitudinal anneal for comparable $B_{M}$ and f. However, Figures 9 and 10 do not quickly show quantifiably how much better the $S C L$ is for $2714 \mathrm{AF}$ than for $2714 \mathrm{~A}$. By plotting the $S C L$ ratio of $2714 \mathrm{~A}$ to $2714 \mathrm{AF}$, the clear advantage of $2714 \mathrm{AF}$ is readily seen. Figure 11 is a plot of the $S C L$ ratio of $2714 \mathrm{~A}$ to $2714 \mathrm{AF}$ versus $B_{M}$ for three frequencies at $23{ }^{\circ} \mathrm{C}$. Figure 12 is a plot of this same $S C L$ ratio versus $f$ for four $B_{M}$ values. The $S C L$ curves in Figure 11 show that the $S C L$ ratio decreases as $B_{M}$ increases with the lowest frequency giving the largest ratio. The curves in Figure 12 show that the $S C L$ ratio decreases as $f$ increases with the lowest $B_{M}$ giving the largest ratio. The results in the two figures show that the $S C L$ advantage of $2714 \mathrm{AF}$ over $2714 \mathrm{~A}$ is greatest at low $B_{M}$ and low $f$ and that this advantage diminishes as either $B_{M}$ or $f$ increases. For example, at $20 \mathrm{kHz}$ and $B_{M}=0.1$ Tesla, the ratio is 5.4 while for this same frequency and $B_{M}=0.5$ Tesla, the ratio now decreases to 1.9 . At $100 \mathrm{kHz}$ and $B_{M}=0.1$ Tesla the ratio is 2.8 while for this same frequency and for $B_{M}=0.4$ Tesla, the ratio drops to 1.4. Even though the $S C L$ advantage diminishes with increasing $B_{M}$ or $\mathrm{f}$, the fact remains that the transverse annealed 2714AF material always has lower losses than the longitudinal annealed 2714A material for the frequencies and flux densities tested.

The 2714AF dynamic $B-H$ loops for frequencies 20,50 , and $100 \mathrm{kHz}$ at $B_{M}=0.4$ Tesla and $23{ }^{\circ} \mathrm{C}$ are drawn in Figure 13. When this family of loops is compared to the family of loops for $2714 \mathrm{~A}$ in Figure 5(a), the following is 
observed: (a) The 2714A loops are more squared, i.e., have a higher remanence than the 2714AF loops, (b) the 2714AF loops are skewed or tilted to the right relative to the 2714A loops, and (c) a 2714A loop has more enclosed area than a 2714AF loop for any given frequency. A more direct comparison of the $2714 \mathrm{~A}$ and the $2714 \mathrm{AF}$ dynamic $B-H$ loops for $100 \mathrm{kHz}, 0.4$ Tesla is displayed in Figure 14. This figure quickly shows that the 2714AF loop is entirely enclosed in the 2714A loop except for the small areas about $\pm B_{M}$. Figure 14 gives both a good picture of the loss advantage of $2714 \mathrm{AF}$ over $2714 \mathrm{~A}$ and also the tilt of the $2714 \mathrm{AF}$ loop relative to the $2714 \mathrm{~A}$ loop.

\section{SCL Comparison of Different Materials}

Of special interest and of great help to the magnetic component designer are $S C L$ plots comparing various candidate soft magnetic materials over a range of flux densities and frequencies. $S C L$ plots of this type reduce design time as they enable the designer to judiciously select the best material for the given design frequency and flux density.

Figure 15 gives a plot of the $S C L$ versus $B_{M}$ at $100 \mathrm{kHz}$ and $23{ }^{\circ} \mathrm{C}$ for four different materials which includes not only the 2714A and 2714AF materials reported in this paper, but also the transverse annealed amorphous $6025 \mathrm{~F}$ material manufactured by Vacuumschmelze, and poly crystalline Supermalloy material. The $S C L$ for Supermalloy is given for 1-mil and 1/4-mil thick tape. Also, the $S C L$ for both sine and square wave voltage excitation are given for 2714A. The curves in Figure 15 show that the $S C L$ for the transverse annealed 2714AF and 6025F materials yield the lowest losses with the $6025 \mathrm{~F}$ material giving slightly lower $S C L$ at low flux densities and slightly higher $S C L$ at the higher flux densities compared to the 2714AF material. This figure also shows that the $S C L$ for the polycrystalline 1/4-mil Supermalloy is much better than the longitudinal annealed 2714A for low $B_{M}$, but this advantage is almost eliminated as $B_{M}$ approaches 0.3 Tesla.

Figure 16 gives a plot of the $S C L$ versus $f$ at $B_{M}=0.1$ Tesla and $23{ }^{\circ} \mathrm{C}$ for the same materials shown in Figure 15 . Again it is seen from this figure that the transverse annealed $2714 \mathrm{AF}$ and $6025 \mathrm{~F}$ give the lowest $S C L$, but $6025 \mathrm{~F}$ shows slightly lower $S C L$ compared to $2714 \mathrm{AF}$. Of special interest to note is that the 1/4-mil Supermalloy has a lower $S C L$ over the entire frequency range compared to the longitudinal annealed amorphous 2714A. Also it is interesting to note that the 1-mil Supermalloy has lower $S C L$ than the 2714A up to $20 \mathrm{kHz}$.

\section{Summary and Conclusion}

An experimental study was conducted to investigate the combined effects of temperature and sine or square wave voltage excitation on the $S C L$ and dynamic $B-H$ hysteresis loops of the longitudinal magnetic field annealed amorphous Metglas ${ }^{\circledR} 2714 \mathrm{~A}$ material. For the same $B_{M}, f$, and $T$, the $S C L$ was always lower for the square than the sine wave voltage excitation. In comparing the polycrystalline Supermalloy to Metglas ${ }^{\circledR} 2714 \mathrm{~A}$, it was found that the ratio of sine-to-square wave $S C L$ was greater for Supermalloy than for $2714 \mathrm{~A}$ at $B_{M}=0.4$ Tesla and $T=23{ }^{\circ} \mathrm{C}$. The underlying reason for this is not immediately apparent and needs to be explored if this difference is to be attributed solely to the classical eddy current loss component of the total core loss. The effect of temperature on the $S C L$ of $21714 \mathrm{~A}$ for both sine and square wave voltage excitation was found to be minimal from 23 to $100{ }^{\circ} \mathrm{C}$ for $B_{M}$ $=0.4$ Tesla, but with a noticeable increase in $S C L$ from 100 to $150{ }^{\circ} \mathrm{C}$ with the increase being more pronounced with increasing frequency.

An experimental study was also conducted to investigate the effect of a transverse magnetic field annealed material on the SCL. A comparison of the SCL of 2714A (longitudinal magnetic field anneal) with 2714AF (transverse magnetic field anneal) found that 2714AF always had a lower $S C L$ than 2714A for any given $B_{M}$ and $f$. In particular, it was found that the $S C L$ ratio of $2714 \mathrm{~A}$ to $2714 \mathrm{AF}$ was dependent on $B_{M}$ and $f$ and that the highest ratio occurred for the lowest $B_{M}$ and $f$ for decreasing ratio with either increasing $B_{M}$ or $f$.

Finally, a comparison of the 2714A and 2714AF materials was made to another transverse magnetic annealed amorphous material, 6025F, manufactured by Vacuumschmelze and two different tape thicknesses of the polycrystalline material, Supermalloy. From the magnetic component designer's viewpoint, the best material to use from this comparison in terms of $S C L$ is either $2714 \mathrm{AF}$ or $6025 \mathrm{~F}$ which have comparable losses at $100 \mathrm{kHz}$ from $B_{M}$ $=0.1$ to 0.4 Tesla. This comparison also shows that the $1 / 4$-mil thick tape Supermalloy has a lower $S C L$ than the longitudinal annealed 2714A over the entire frequency range and magnetic flux density range investigated. The comparison also shows that the $S C L$ of the 1-mil thick tape Supermalloy is competitive with the 2714A at low $B_{M}$ and $f$. 


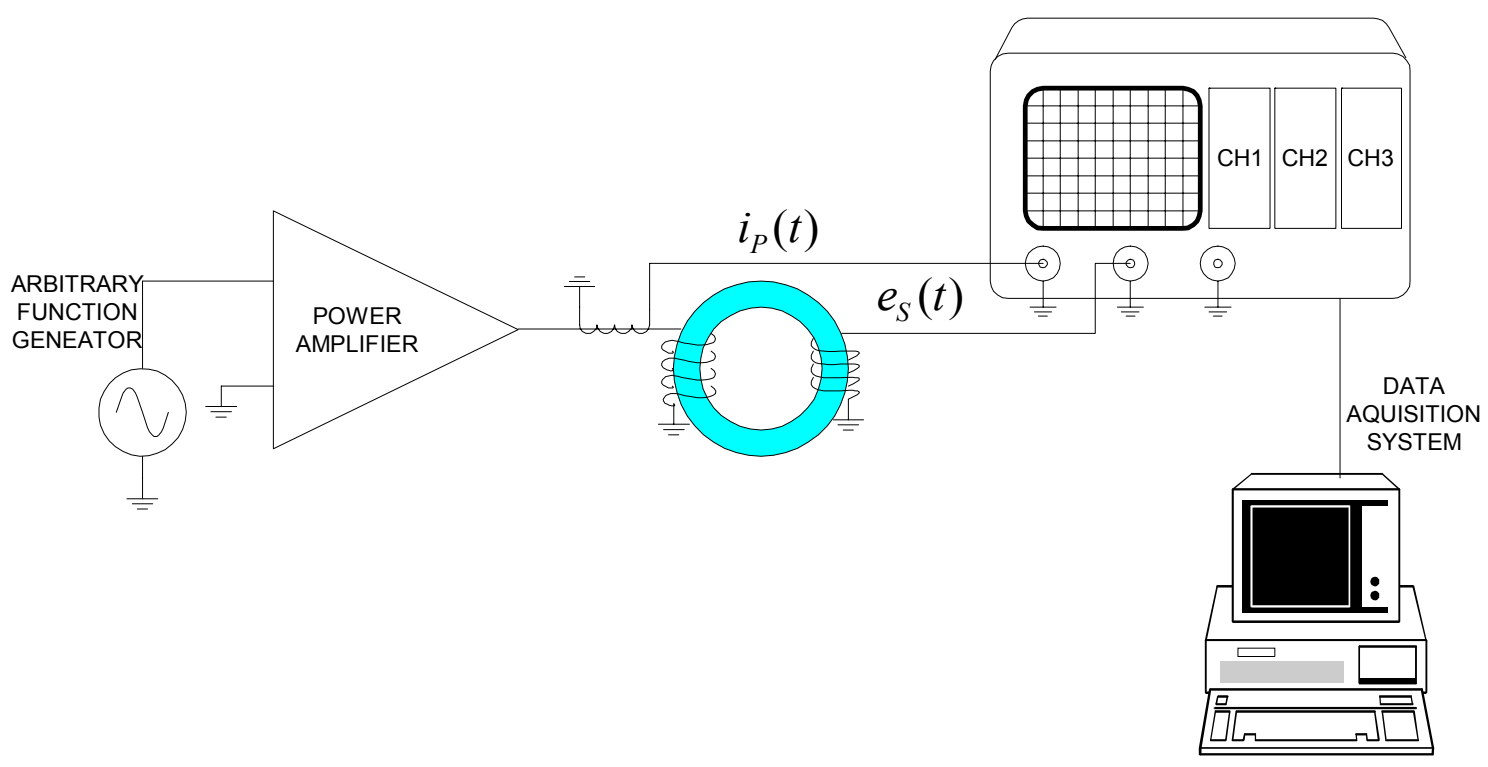

Figure 1.-Specific loss and dynamic $B-H$ hysteresis loop measurement system. 


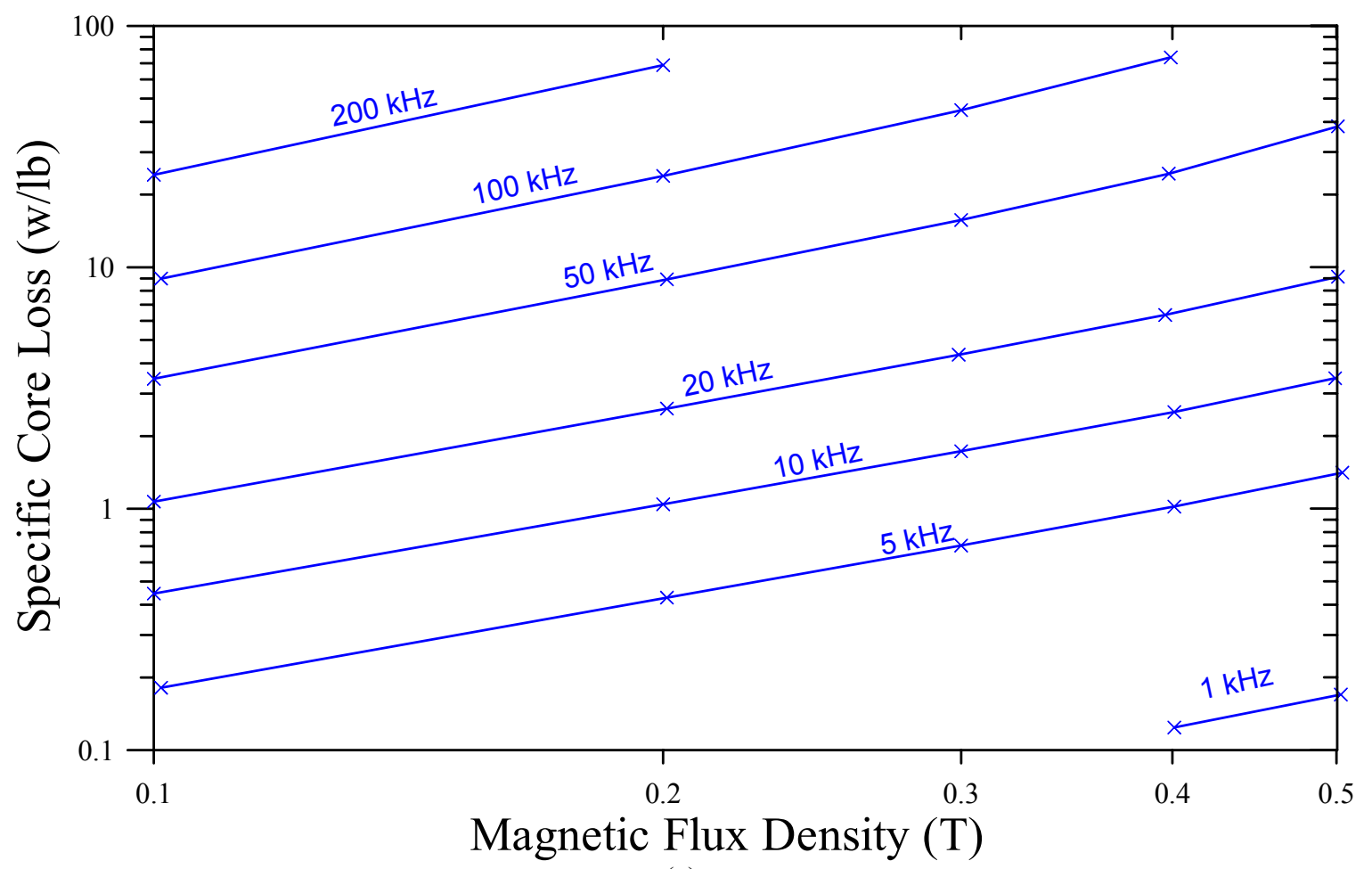

(a)

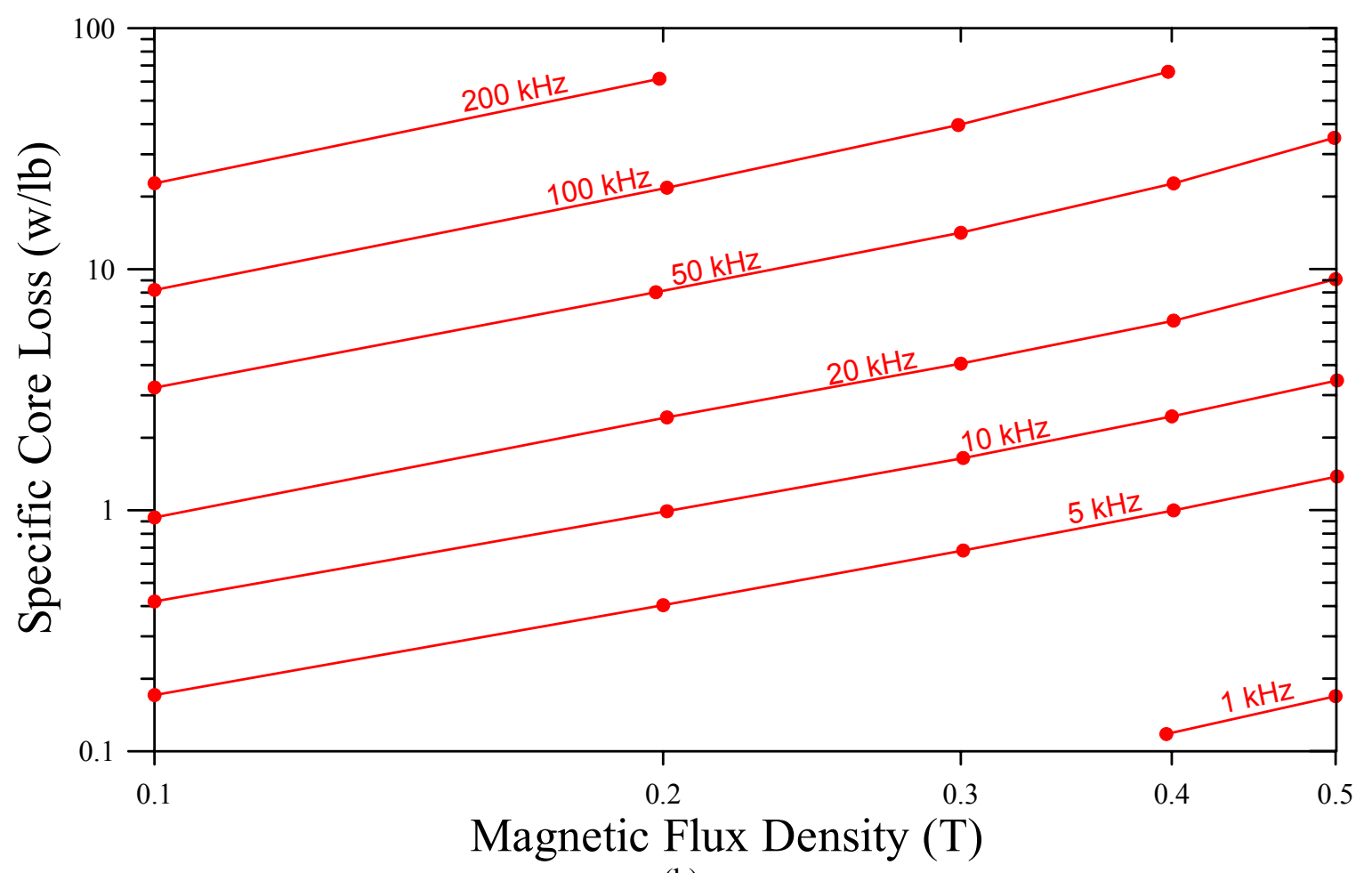

(b)

Figure 2.-Metglas ${ }^{\circledR} 2714 \mathrm{~A}$ specific core loss versus maximum flux density at $23{ }^{\circ} \mathrm{C}$ with frequency as parameter for nominal $20 \mu \mathrm{m}$ thick tape toroid. (a) Sine wave voltage excitation, (b) Square wave voltage excitation. 


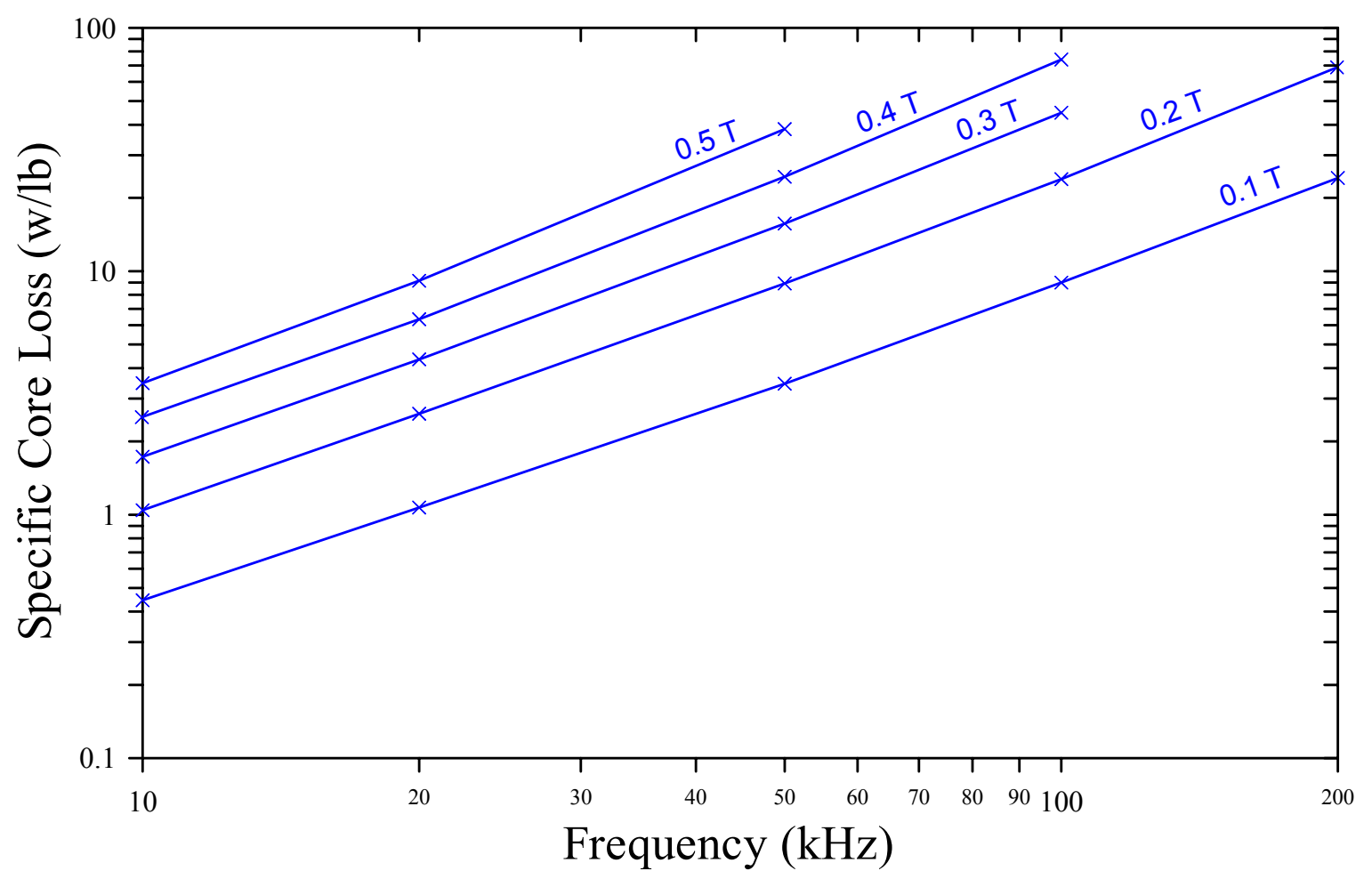

(a)

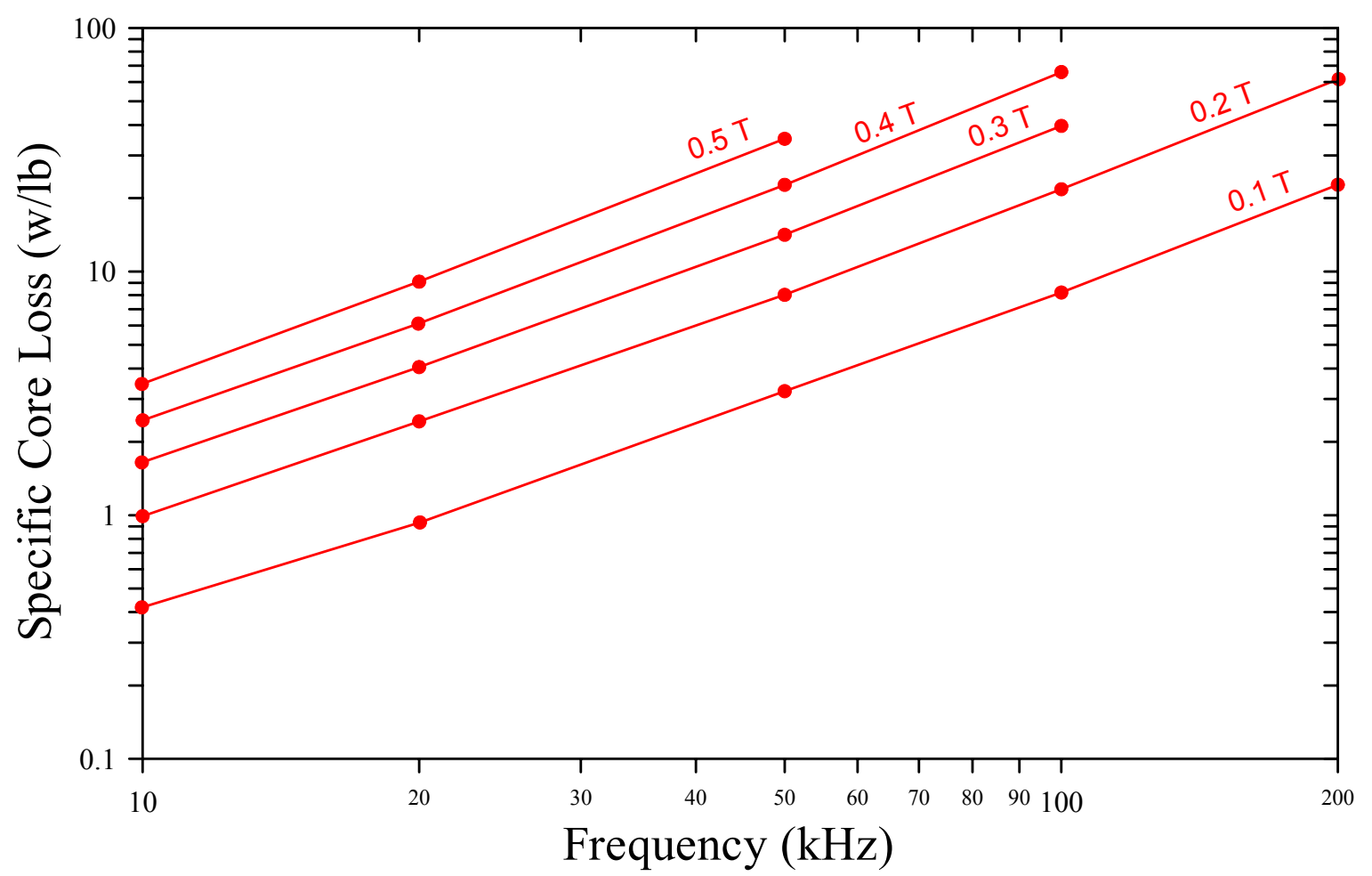

(b)

Figure 3.-Metglas ${ }^{\circledR} 2714 \mathrm{~A}$ specific core loss versus frequency at $23{ }^{\circ} \mathrm{C}$ with maximum flux density as parameter for nominal $20 \mu \mathrm{m}$ thick tape toroid. (a) Sine wave voltage excitation, (b) Square wave voltage excitation. 


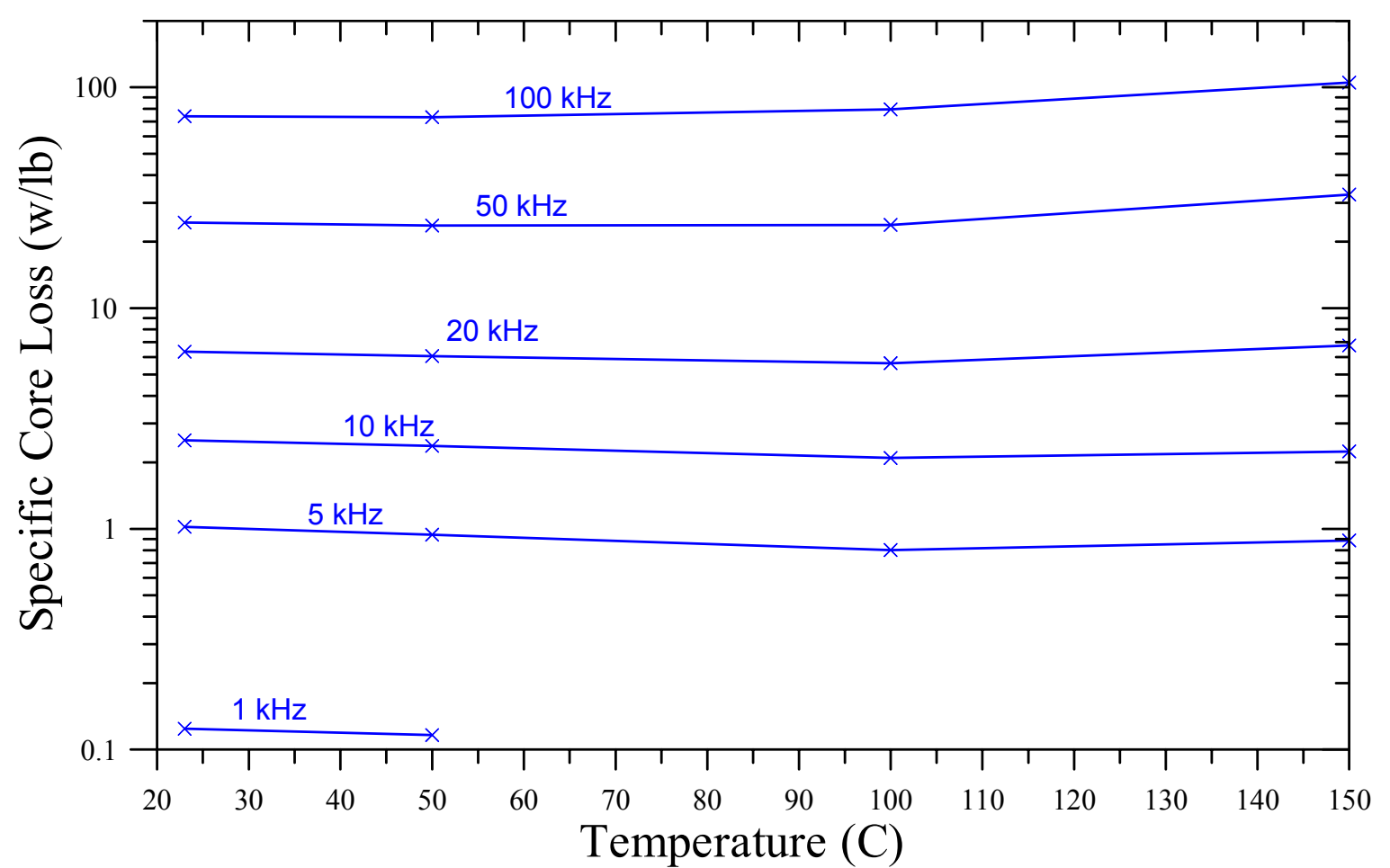

(a)

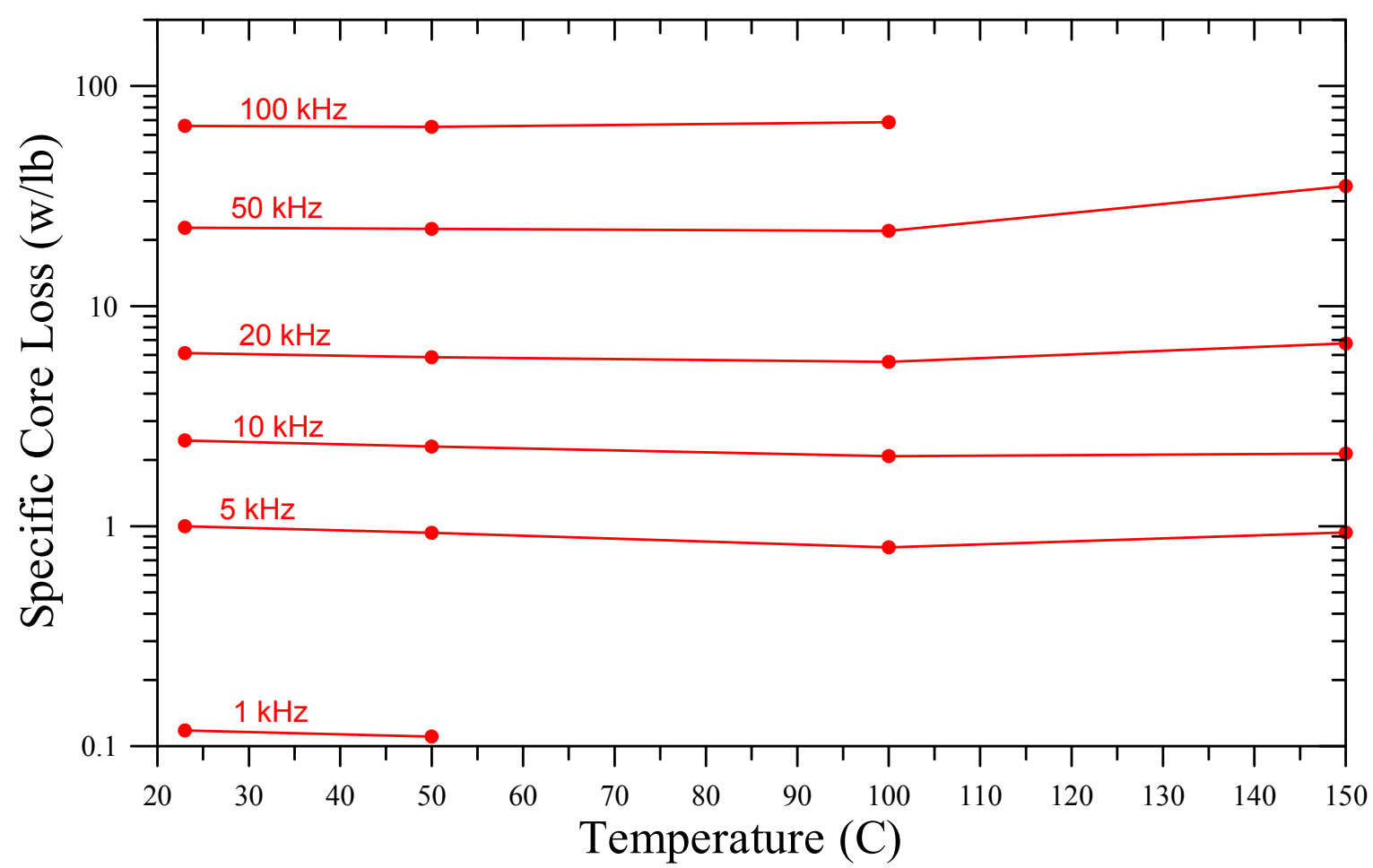

(b)

Figure 4.-Metglas ${ }^{\circledR} 2714 \mathrm{~A}$ specific core loss versus temperature at $B_{M}=0.4$ Tesla with frequency as the parameter for a nominal $20 \mu \mathrm{m}$ thick tape toroid. (a) Sine wave voltage excitation, (b) Square wave voltage excitation. 


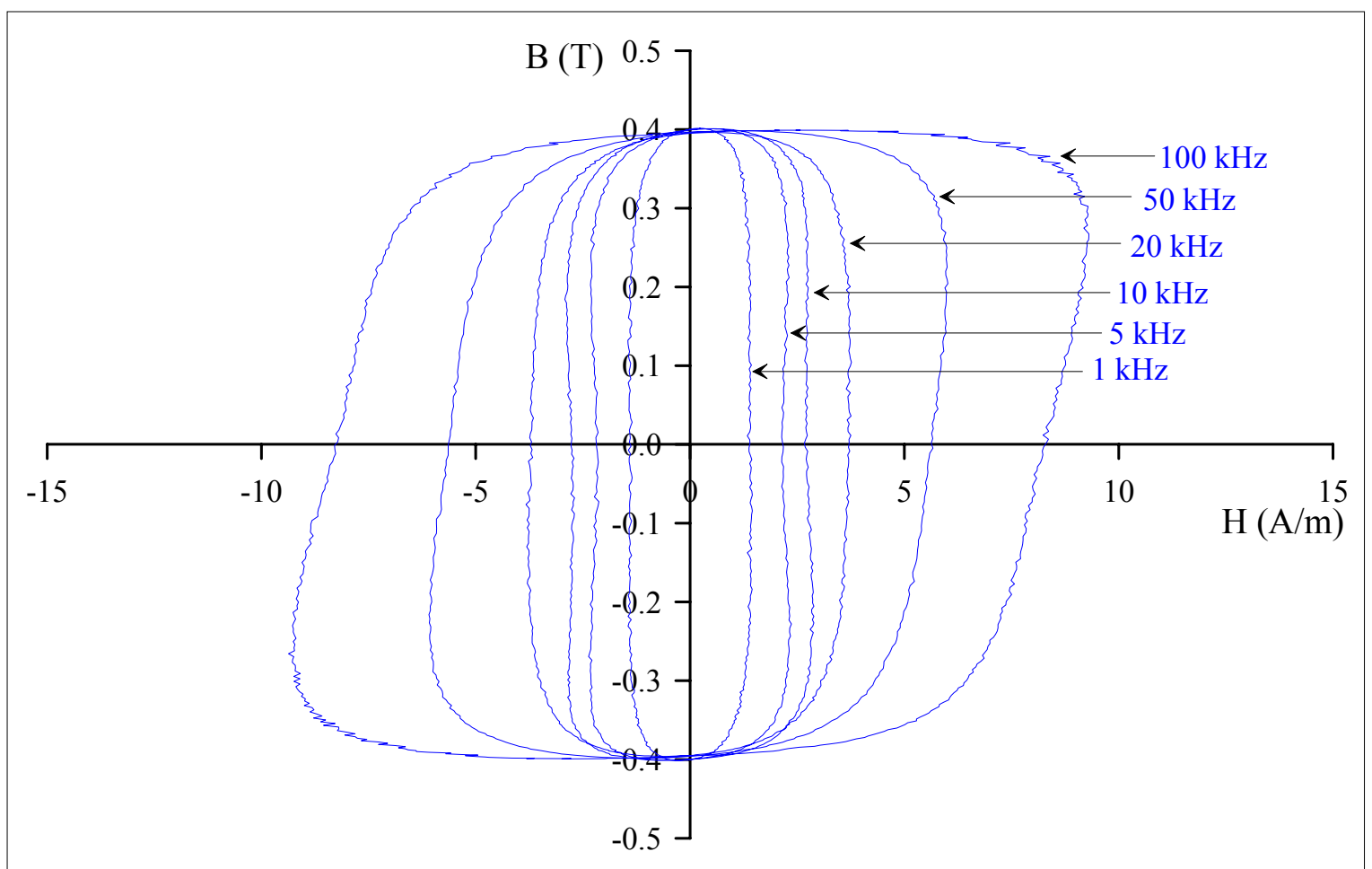

(a)

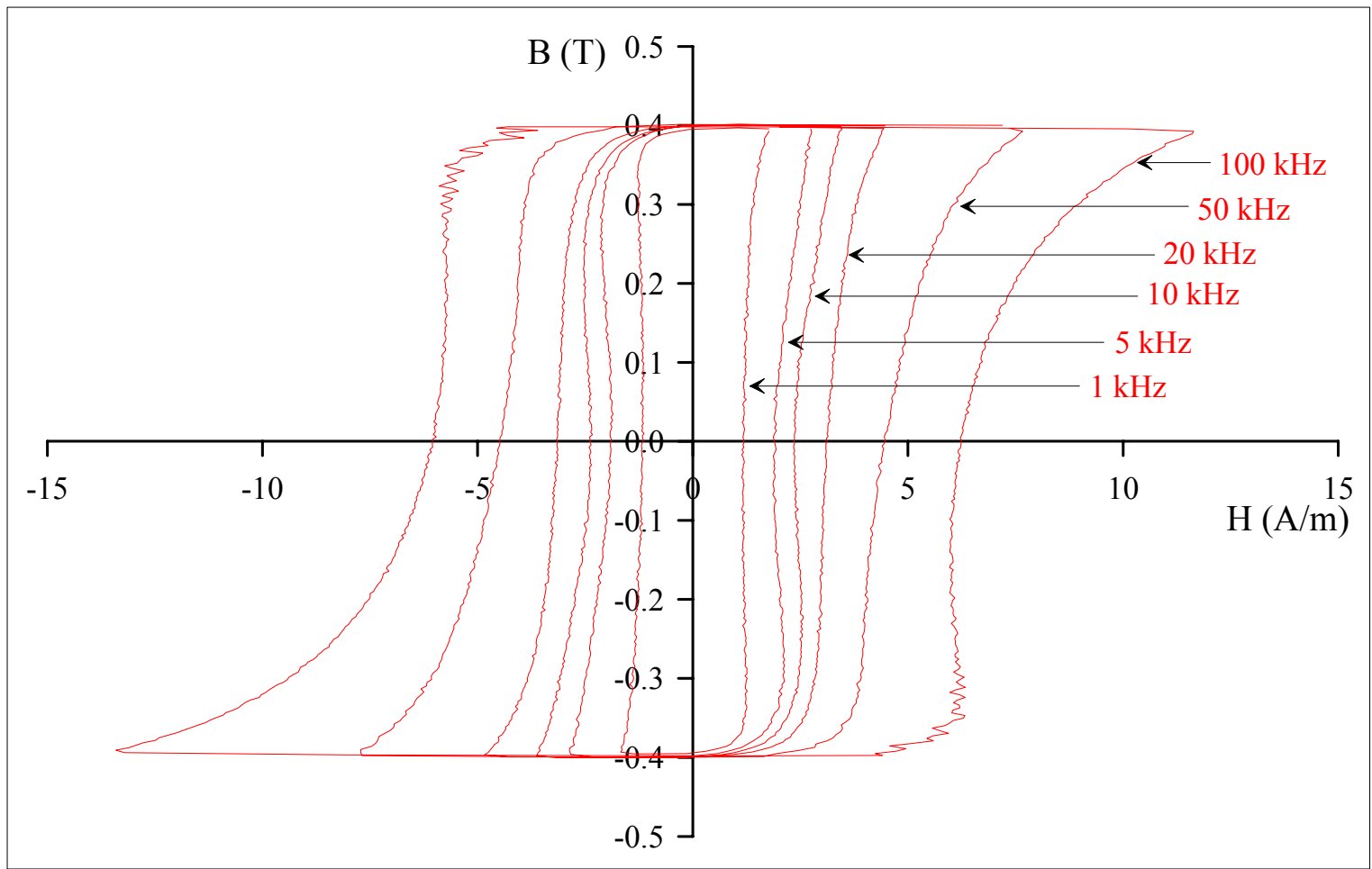

(b)

Figure 5.-Metglas ${ }^{\circledR} 2714 \mathrm{~A}$ family of dynamic $B$ - $H$ loops at $23{ }^{\circ} \mathrm{C}$ for various frequencies at $B_{M}=0.4$ Tesla for a nominal $20 \mu \mathrm{m}$ thick tape toroid. (a) Sine wave voltage excitation, (b) Square wave voltage excitation. 


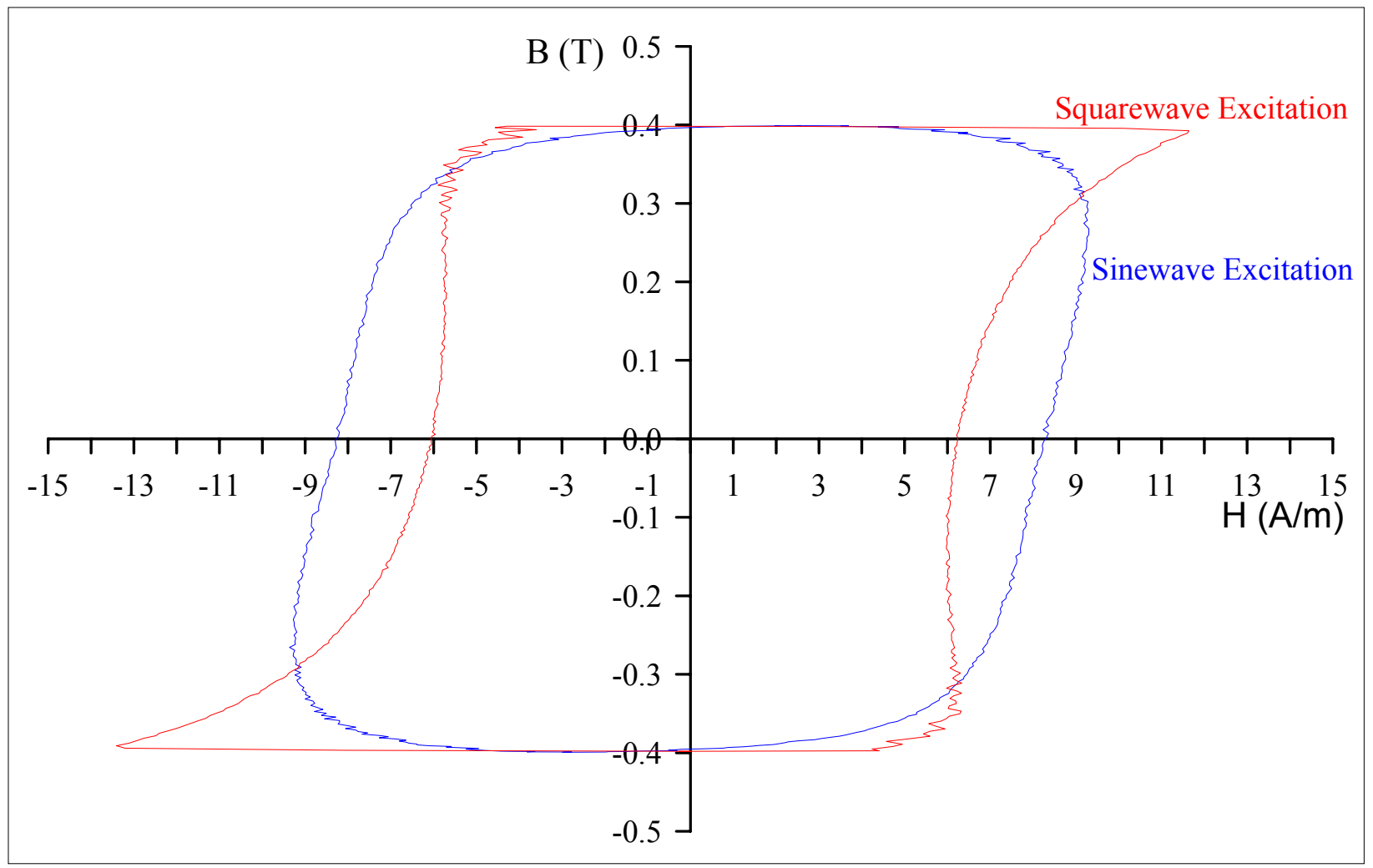

Figure 6.-Comparison of a nominal $20 \mu \mathrm{m}$ thick tape toroid Metglas ${ }^{\circledR} 2714 \mathrm{~A}$ dynamic $B-H$ loops for sine and square wave voltage excitation at $23{ }^{\circ} \mathrm{C}, B_{M}=0.4$ Tesla, and $f=100 \mathrm{kHz}$. 


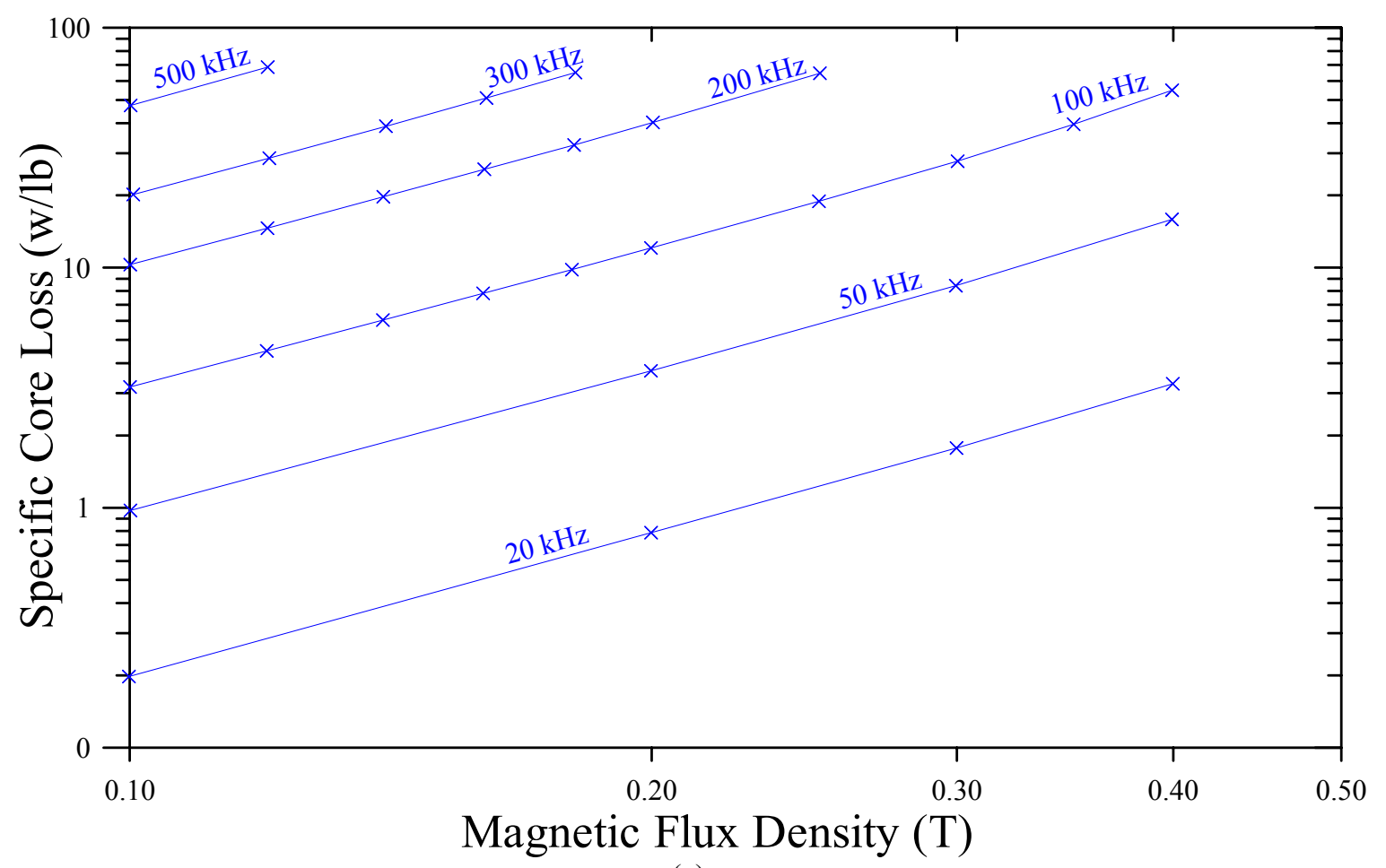

(a)

Figure 7.-Metglas ${ }^{\circledR} 2714 \mathrm{AF}$ specific core loss versus maximum magnetic flux density at $23{ }^{\circ} \mathrm{C}$ with frequency as the parameter for sine wave voltage excitation for a nominal $20 \mu \mathrm{m}$ thick tape toroid.

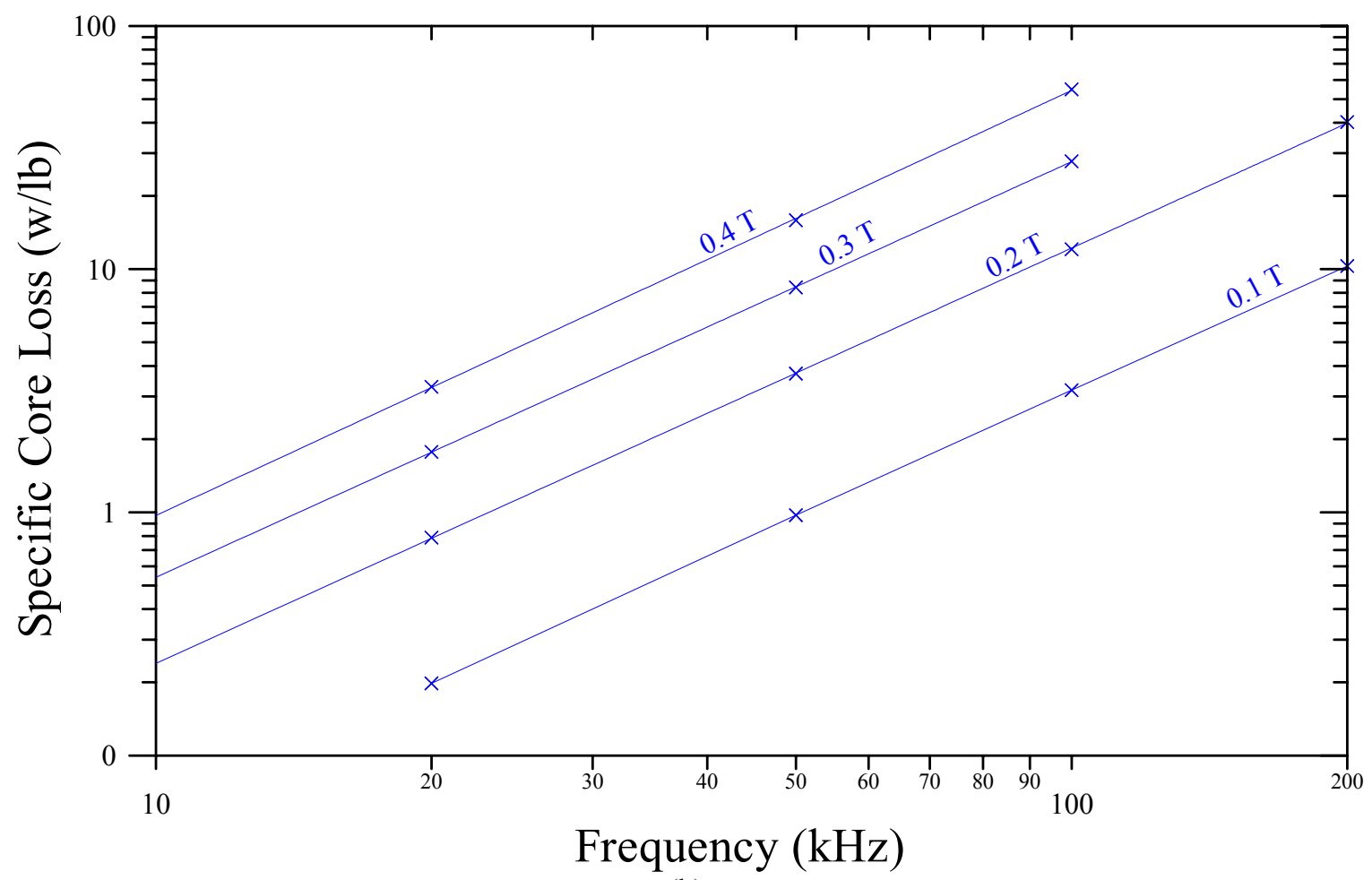

(b)

Figure 8.-Metglas ${ }^{\circledR} 2714 \mathrm{AF}$ specific core loss versus frequency at $23{ }^{\circ} \mathrm{C}$ with maximum magnetic flux density as the parameter for a nominal $20 \mu \mathrm{m}$ thick tape toroid. 


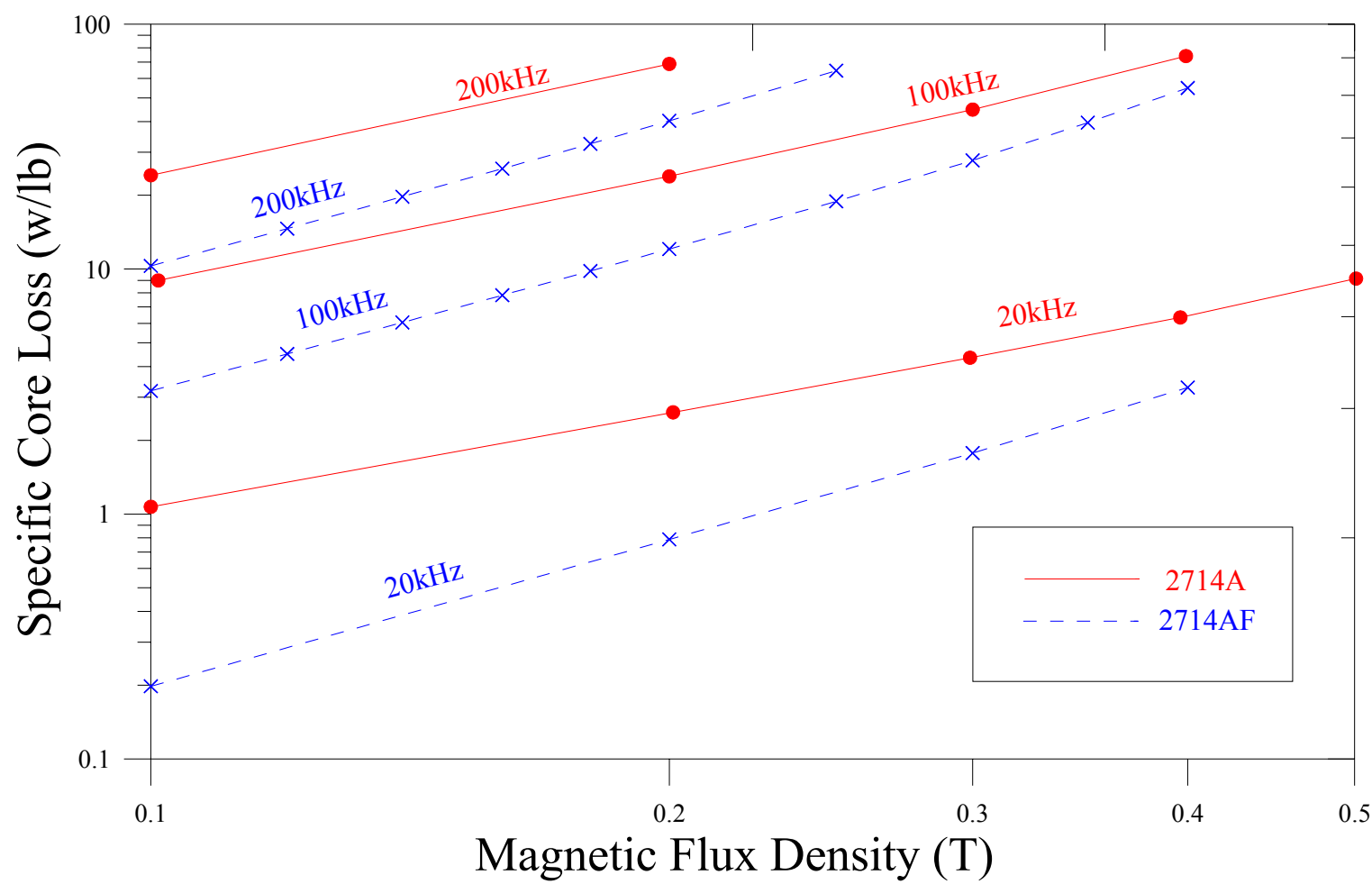

Figure 9.-Comparison of Metglas ${ }^{\circledR} 2714 \mathrm{~A}$ to $2714 \mathrm{AF}$ specific core loss versus maximum magnetic flux density at $23{ }^{\circ} \mathrm{C}$ with frequency as the parameter for sine wave voltage excitation for nominal $20 \mu \mathrm{m}$ thick tape toroid.

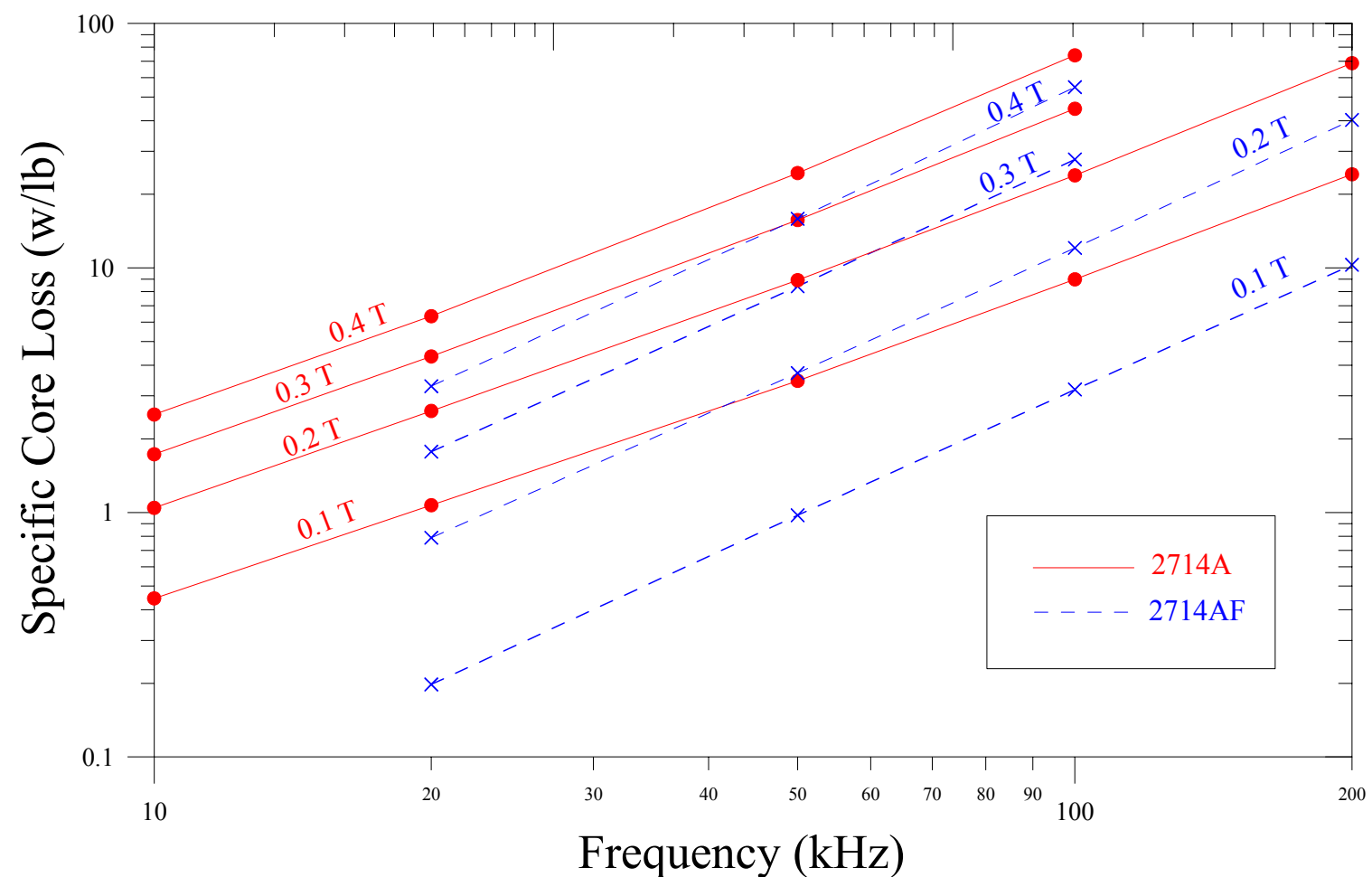

Figure 10.-Comparison of Metglas ${ }^{\circledR} 2714 \mathrm{~A}$ to $2714 \mathrm{AF}$ specific core loss versus frequency at $23{ }^{\circ} \mathrm{C}$ with maximum flux density as the parameter for sine wave voltage excitation for nominal $20 \mu \mathrm{m}$ thick tape toroid. 


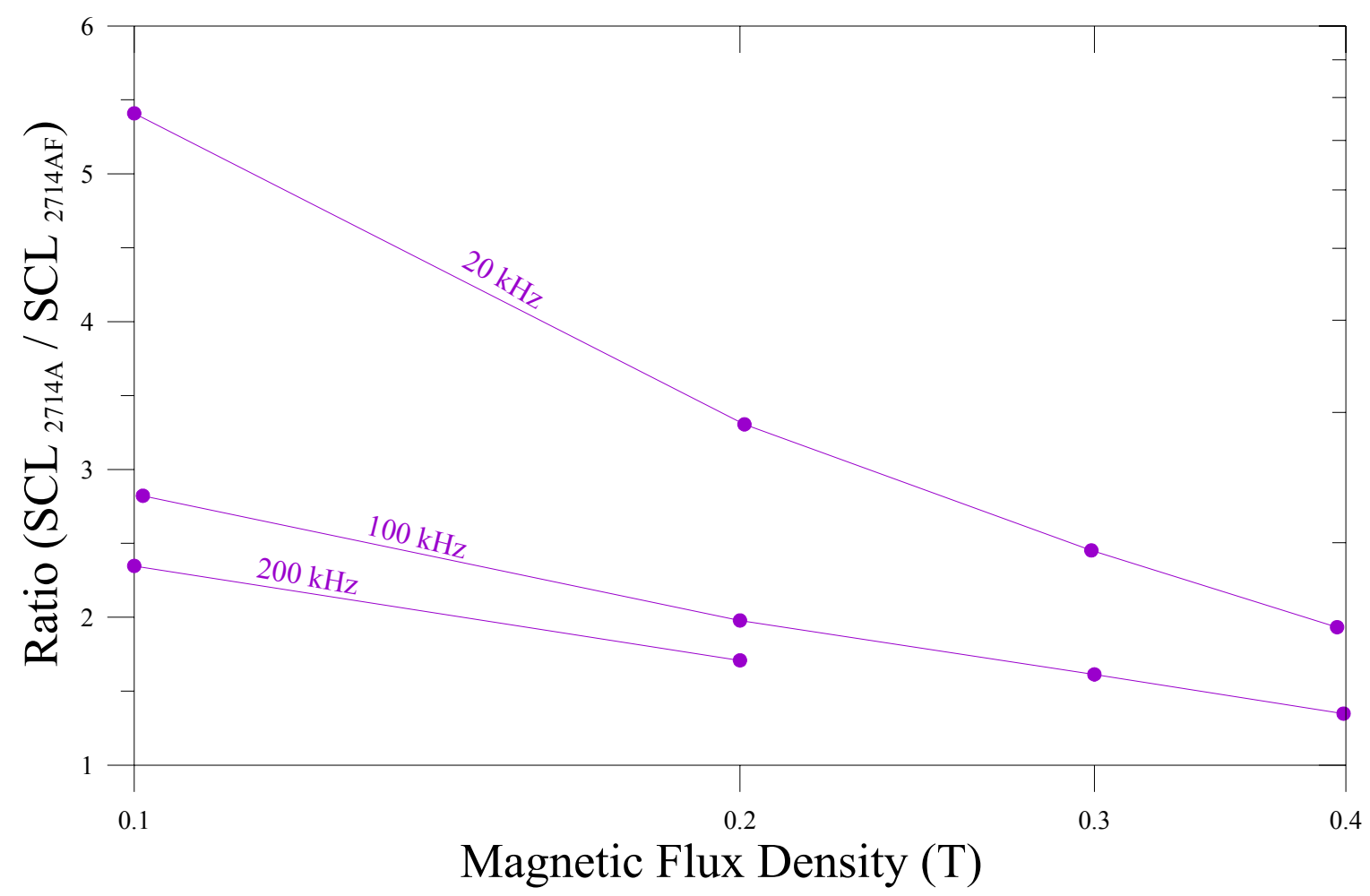

Figure 11.- Specific core loss ratio of Metglas ${ }^{\circledR} 2714 \mathrm{~A}$ to $2714 \mathrm{AF}$ material versus maximum magnetic flux density at $23{ }^{\circ} \mathrm{C}$ for three frequencies for sine wave voltage excitation for nominal $20 \mu \mathrm{m}$ thick tape toroids.

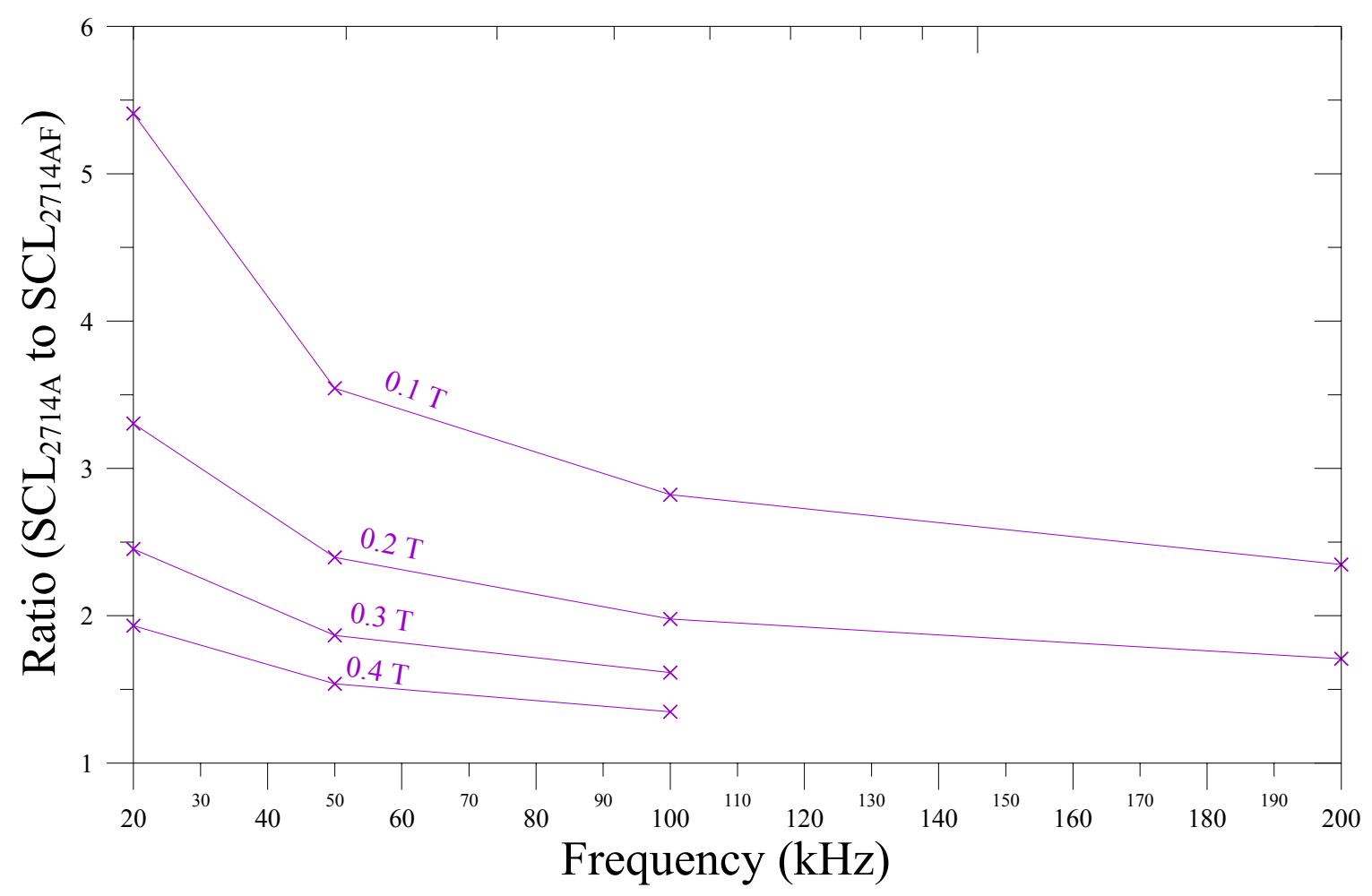

Figure 12.- - Specific core loss ratio of Metglas ${ }^{\circledR} 2714 \mathrm{~A}$ to $2714 \mathrm{AF}$ material versus frequency at $23{ }^{\circ} \mathrm{C}$ for four maximum magnetic flux densities for sine wave voltage excitation for nominal $20 \mu \mathrm{m}$ thick tape toroids. 


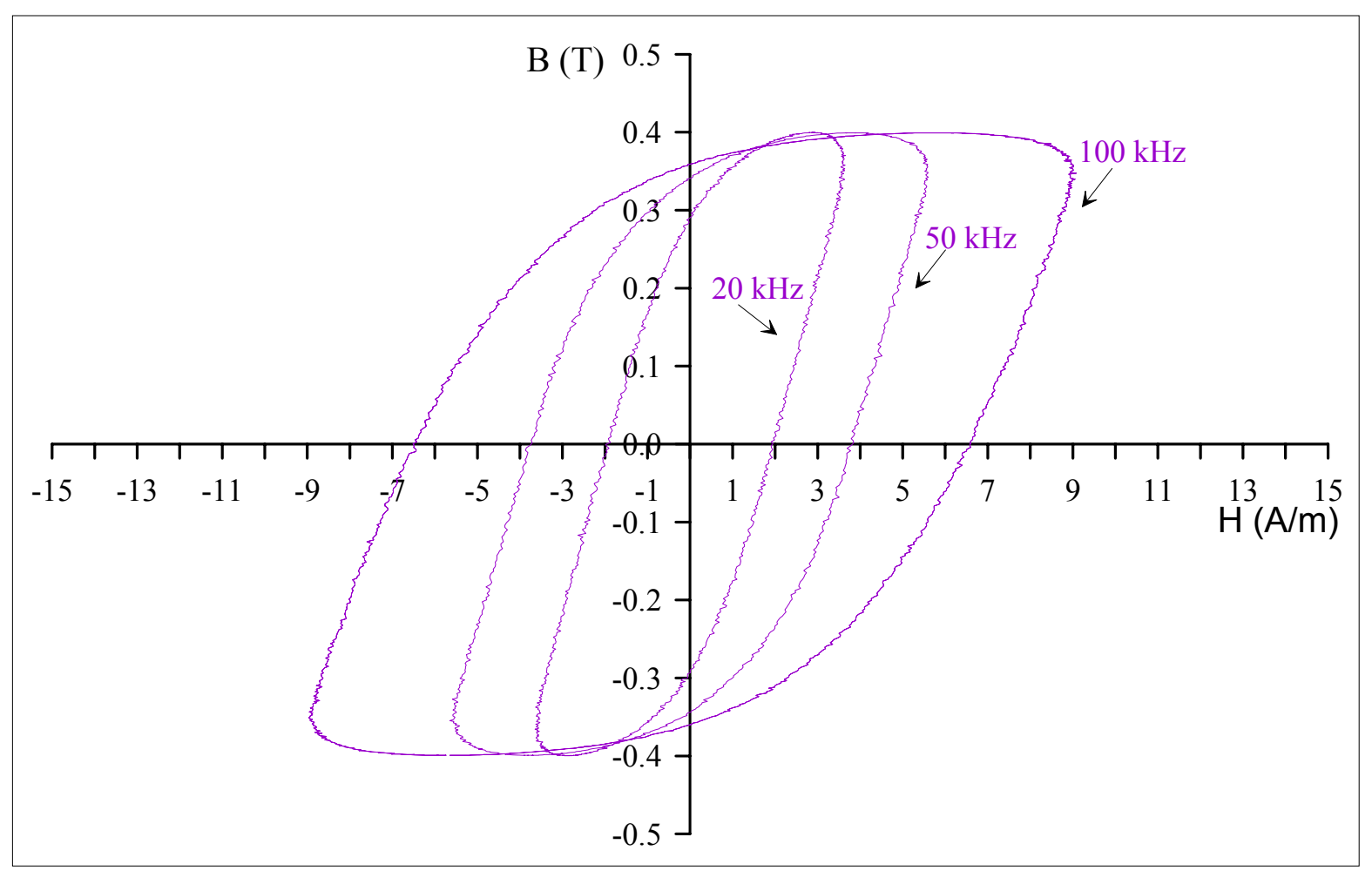

Figure 13.-Metglas ${ }^{\circledR} 2714 \mathrm{AF}$ family of dynamic $B-H$ loops at $23^{\circ} \mathrm{C}$ for various frequencies at $B_{M}=0.4$ Tesla for sine wave voltage excitation for a nominal $20 \mu \mathrm{m}$ thick tape toroid.

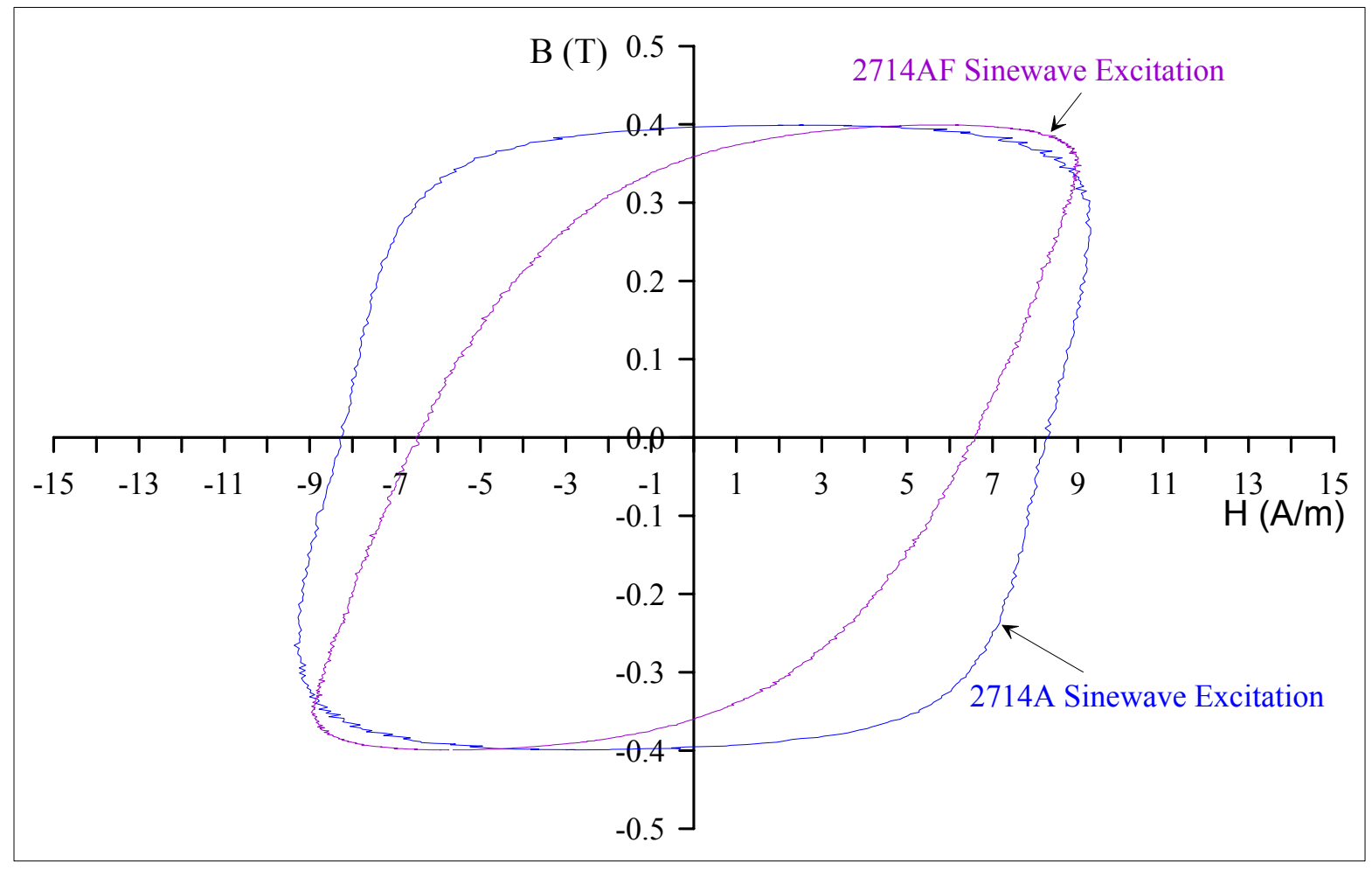

Figure 14.-Comparison for nominal $20 \mu \mathrm{m}$ thick tape toroids Metglas ${ }^{\circledR}$ 2714A to 2714AF dynamic $B$ - $H$ loops for sine wave voltage excitation at $23{ }^{\circ} \mathrm{C}, B_{M}=0.4$ Tesla, and $f=100 \mathrm{kHz}$. 


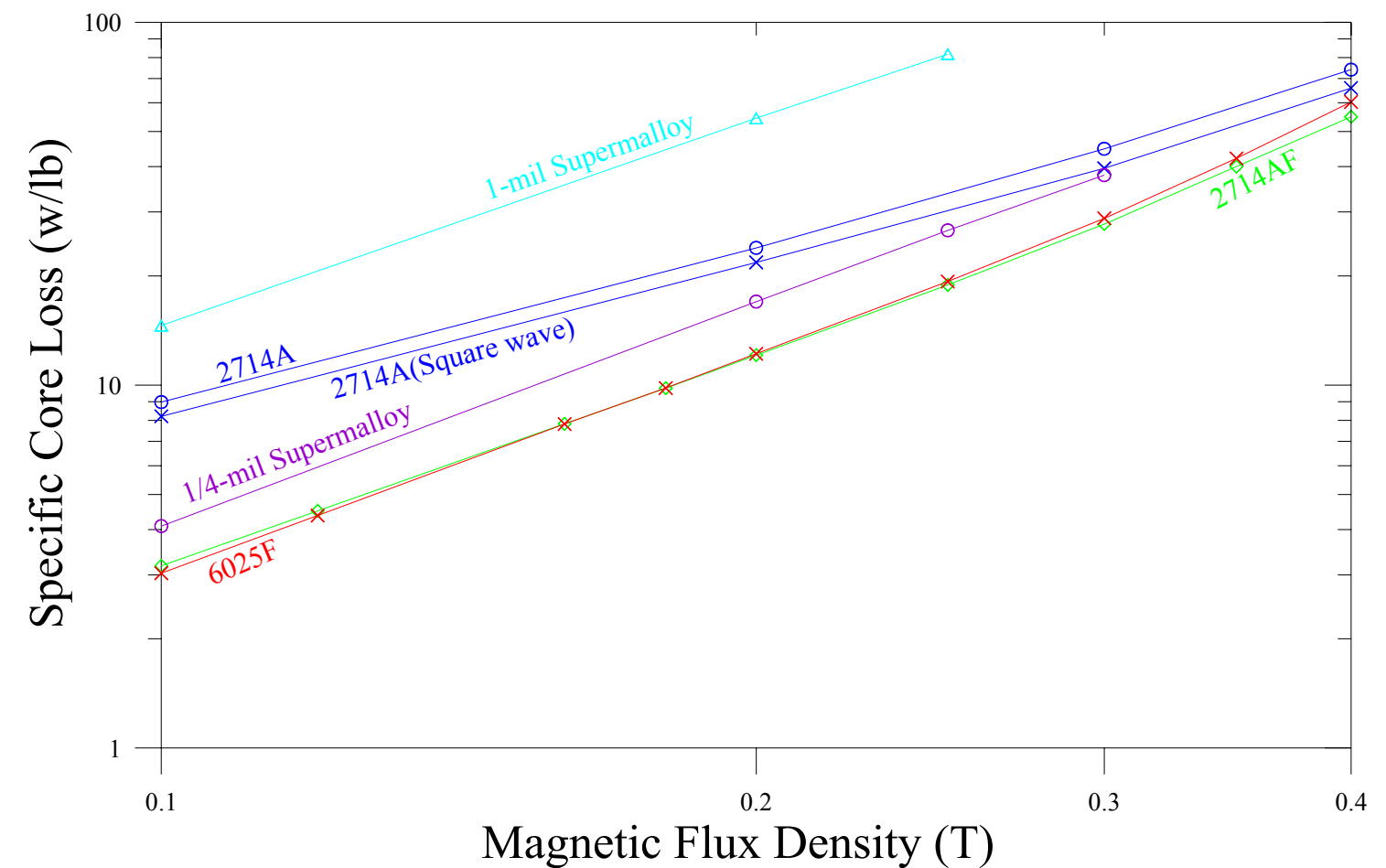

Figure 15.-Comparison of the specific core loss versus maximum magnetic flux density of different magnetic materials for sine wave voltage excitation, except where noted, at $23^{\circ} \mathrm{C}$ and $100 \mathrm{kHz}$.

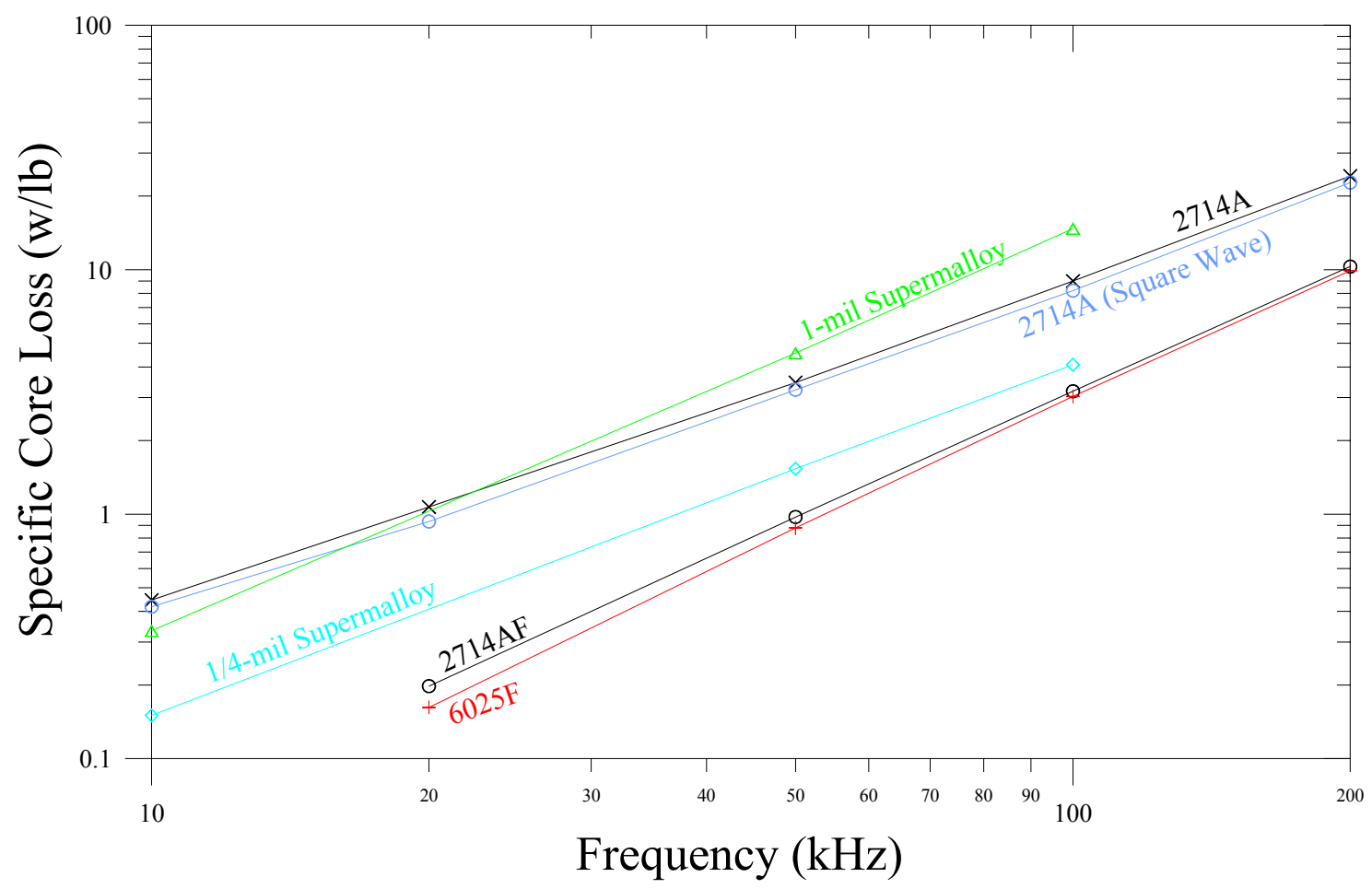

Figure 16.-Comparison of the specific core loss versus frequency of different magnetic materials for sine wave voltage excitation, except where noted, at $23^{\circ} \mathrm{C}$ and $B_{M}=0.1$ Tesla. 


\section{References}

${ }^{1}$ Schwarze, G.E., "Development of High Frequency Low Weight Power Magnetics for Aerospace Power Systems", Nineteenth Intersociety Energy Conversion Engineering Conference, San Francisco, CA, August 19-24, 1984.

${ }^{2}$ Wieserman, W.R., Schwarze, G.E., and Niedra, J.M., "High Frequency, High Temperature Specific Core Loss and Dynamic BH Hysteresis Loop Characteristics of Soft Magnetic Alloys", $25^{\text {th }}$ Intersociety Energy Conversion Engineering Conference, Reno, Nevada, August 12-17, 1990.

${ }^{3}$ Wieserman, W. R., Schwarze, G. E., and Niedra, J. M, "Comparison of High Frequency, High Temperature Core Loss and B-H Loop Characteristics of an 80 Ni-Fe Crystalline Alloy and Two Iron-Based Amorphous Alloys," Eighth Symposium on Space Nuclear Power Systems Proceedings, Part Three, Albuquerque, N.M., January 6-10, 1991.

${ }^{4}$ Wieserman, W. R., Schwarze, G. E., and Niedra, J. M, "Comparison of High Temperature, High Frequency Core Loss and Dynamic B-H Loops of Two 50 Ni-Fe Crystalline Alloys and an Iron-Based Amorphous Alloy”, $26^{\text {th }}$ Intersociety Energy Conversion Engineering Conference Proceedings, Boston, MA, August 4-9, 1991.

${ }^{5}$ Wieserman, W. R., Schwarze, G. E., and Niedra, J. M, "Comparison of High Temperature, High Frequency Core Loss and Dynamic B-H Loops of a 2V-49Fe-49Co and a Grain Oriented 3Si-Fe Alloy", $27^{\text {th }}$ Intersociety Energy Conversion Engineering Conference, San Diego, CA, August 3-7, 1992.

${ }^{6}$ Schwarze, G. E., Wieserman, W. R., and Niedra, J. M, "Effects of Temperature, Frequency, Flux Density and Excitation Waveform on the Core Loss and Dynamic B-H Loops of Supermalloy“, $30^{\text {th }}$ Intersociety Energy Conversion Engineering Conference, Orlando, FL, July 31-August 4, 1995.

${ }^{7}$ Niedra, J.M., Schwarze, G. E., "Wide Temperature Core Loss Characteristics of Transverse Magnetically Annealed Amorphous Tapes for High Frequency Aerospace Magnetics“, 34th Intersociety Energy Conversion Engineering Conference, Vancouver, British Columbia, Canada, August 1-5, 1999.

${ }^{8}$ Schwarze, G.E., Wieserman, W.R., and Niedra, J.M., "Magnetic and Electrical Characteristics of Permalloy Thin Tape Bobbin Cores", $2^{\text {nd }}$ International Energy Conversion Engineering Conference, Providence, Rhode Island, 16-19 Aug 2004.

9 Sato, T., and Sakaki, Y., "Discussion of Eddy Current Loss Under Square Wave Voltage Excitation", IEEE Transactions on Magnetics, Vol. 24, No 6, November 1988, pp 2904-2906.

${ }^{10}$ Chen, D.Y., "Comparison of High Frequency Magnetic Core Losses under Two Different Driving Conditions: A Sinusoidal Voltage and a Square Wave Voltage", IEEE Power Electronics Specialist Conference, Record 1978, pp. 237-241.

${ }^{11}$ Metglas ${ }^{\circledR}$ Technical Bulletin, www.metglas.com

${ }^{12}$ Metglas ${ }^{\circledR}$ 2714A Cobalt Based Alloy, Material Safety Data Sheet, www.metglas.com 
Public reporting burden for this collection of information is estimated to average 1 hour per response, including the time for reviewing instructions, searching existing data sources, gathering and maintaining the data needed, and completing and reviewing the collection of information. Send comments regarding this burden estimate or any other aspect of this collection of information, including suggestions for reducing this burden, to Washington Headquarters Services, Directorate for Information Operations and Reports, 1215 Jefferson Davis Highway, Suite 1204, Arlington, VA 22202-4302, and to the Office of Management and Budget, Paperwork Reduction Project (0704-0188), Washington, DC 20503.

\begin{tabular}{|l|l|l|}
\hline 1. AGENCY USE ONLY (Leave blank) & $\begin{array}{c}\text { 2. REPORT DATE } \\
\text { December } 2005\end{array}$ & $\begin{array}{r}\text { 3. REPORT TYPE AND DATES COVERED } \\
\text { Technical Memorandum }\end{array}$
\end{tabular}

\section{TITLE AND SUBTITLE}

5. FUNDING NUMBERS

Magnetic and Electrical Characteristics of Cobalt-Based Amorphous Materials and Comparison to a Permalloy Type Polycrystalline Material

6. AUTHOR(S)

WBS-22-612-50-81-12

William R. Wieserman, Gene E. Schwarze, and Janis M. Niedra

7. PERFORMING ORGANIZATION NAME(S) AND ADDRESS(ES)

National Aeronautics and Space Administration

John H. Glenn Research Center at Lewis Field

Cleveland, Ohio 44135-3191
8. PERFORMING ORGANIZATION REPORT NUMBER

E-15321

\section{SPONSORING/MONITORING AGENCY NAME(S) AND ADDRESS(ES)}

National Aeronautics and Space Administration

Washington, DC 20546-0001
10. SPONSORING/MONITORING AGENCY REPORT NUMBER

NASA TM-2005-213997

AIAA-2005-5720

\section{SUPPLEMENTARY NOTES}

Prepared for the Third International Energy Conversion Engineering Conference sponsored by the American Institute of Aeronautics and Astronautics, San Francisco, California, August 15-18, 2005. William R. Wieserman, University of Pittsburgh, Johnstown, 450 Schoolhouse Road, Johnstown, Pennsylvania 15904; Gene E. Schwarze, NASA Glenn Research Center; and Janis M. Niedra, QSS Group, Inc., 21000 Brookpark Road, Cleveland, Ohio 44135. Responsible person, Gene E. Schwarze, organization code RPE, 216-433-6117.

12a. DISTRIBUTION/AVAILABILITY STATEMENT

Unclassified - Unlimited

Subject Category: 33

Available electronically at http://gltrs.grc.nasa.gov

This publication is available from the NASA Center for AeroSpace Information, 301-621-0390.

\section{ABSTRACT (Maximum 200 words)}

Magnetic component designers are always looking for improved soft magnetic core materials to increase the efficiency, temperature rating and power density of transformers, motors, generators and alternators, and energy density of inductors. In this paper, we report on the experimental investigation of commercially available cobalt-based amorphous alloys which, in their processing, were subjected to two different types of magnetic field anneals: A longitudinal magnetic field anneal or a transverse magnetic field anneal. The longitudinal field annealed material investigated was Metglas ${ }^{\circledR}$ 2714A. The electrical and magnetic characteristics of this material were investigated over the frequency range of 1 to $200 \mathrm{kHz}$ and temperature range of 23 to $150{ }^{\circ} \mathrm{C}$ for both sine and square wave voltage excitation. The specific core loss was lower for the square than the sine wave voltage excitation for the same maximum flux density, frequency and temperature. The transverse magnetic field annealed core materials include Metglas ${ }^{\circledR} 2714 \mathrm{AF}$ and Vacuumschmelze 6025F. These two materials were experimentally characterized over the frequency range of 10 to $200 \mathrm{kHz}$ for sine wave voltage excitation and $23^{\circ} \mathrm{C}$ only. A comparison of the $2174 \mathrm{~A}$ to $2714 \mathrm{AF}$ found that $2714 \mathrm{AF}$ always had lower specific core loss than 2714A for any given magnetic flux density and frequency and the ratio of specific core loss of 2714A to 2714AF was dependent on both magnetic flux density and frequency. A comparison was also made of the 2714A, 2714AF, and 6025F materials to two different tape thicknesses of the polycrystalline Supermalloy material and the results show that 2714AF and 6025F have the lowest specific core loss at $100 \mathrm{kHz}$ over the magnetic flux density range of 0.1 to 0.4 Tesla.

\section{SUBJECT TERMS}

Specific core loss; B-H hysteresis loop; Magnetic field anneal; Sine wave voltage excitation; Square wave; Voltage excitation; Permalloy; High frequency; Magnetic measurements; Magnetic cores

\begin{tabular}{|c|c|c|}
\hline $\begin{array}{c}\text { 17. SECURITY CLASSIFICATION } \\
\text { OF REPORT } \\
\text { Unclassified }\end{array}$ & $\begin{array}{c}\text { 18. SECURITY CLASSIFICATION } \\
\text { OF THIS PAGE } \\
\text { Unclassified }\end{array}$ & $\begin{array}{c}\text { 19. SECURITY CLASSIFICATION } \\
\text { OF ABSTRACT } \\
\text { Unclassified }\end{array}$ \\
\hline
\end{tabular}

15. NUMBER OF PAGES 23

16. PRICE CODE 20. LIMITATION OF ABSTRACT

Standard Form 298 (Rev. 2-89) 

